Prepared in cooperation with the Texas State Soil and Water Conservation Board

Linkage of the Soil and Water Assessment Tool and the Texas Water Availability Model to Simulate the Effects of Brush Management on Monthly Storage of Canyon Lake, SouthCentral Texas, 1995-2010

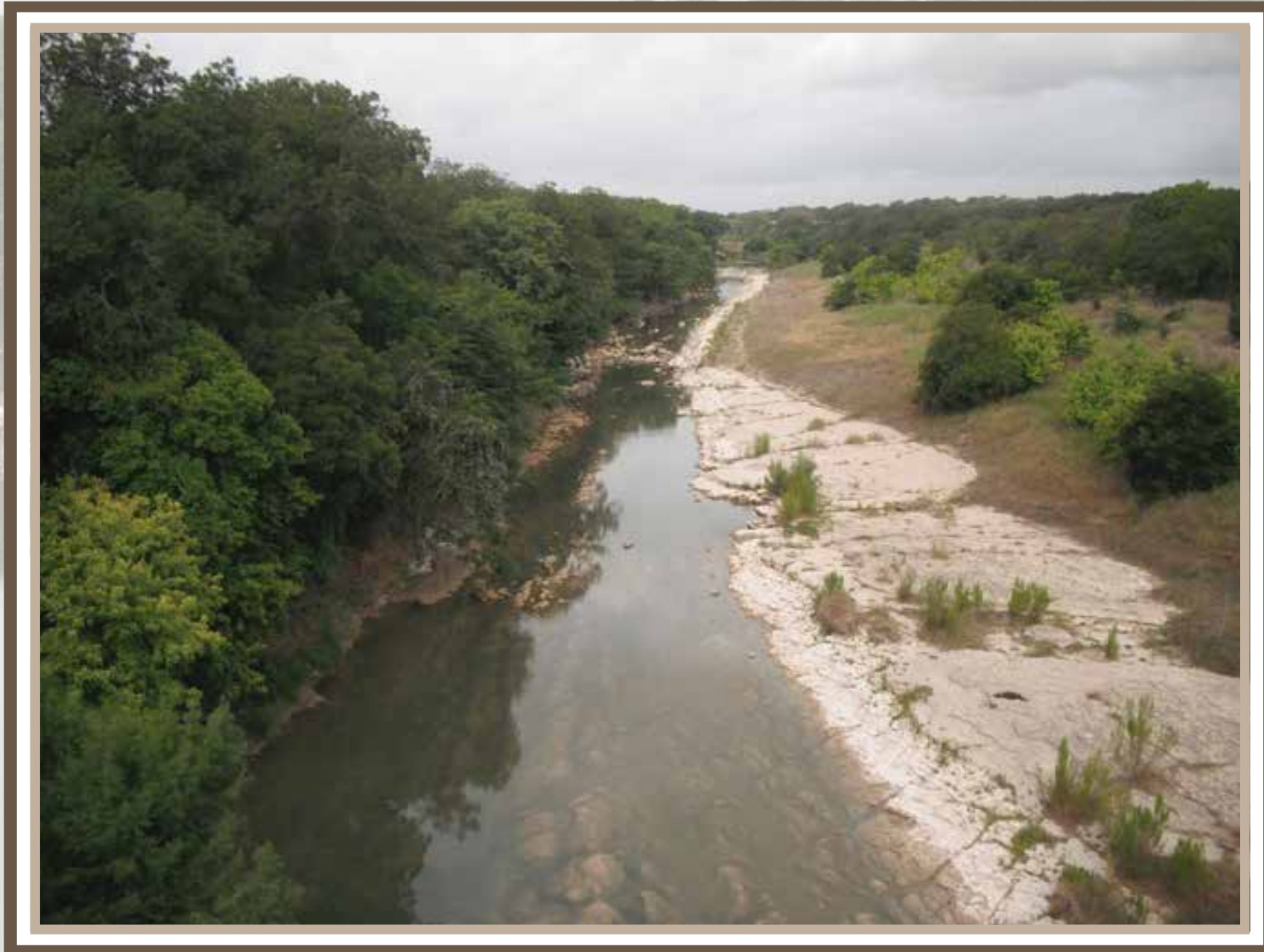

Scientific Investigations Report 2013-5239 
Cover, Upstream from bridge at U.S. Geological Survey streamflow-gaging station 08167500 Guadalupe River near Spring Branch, Texas, dated July 11, 2011, provided by USGS staff. 


\section{Linkage of the Soil and Water Assessment Tool and the Texas Water Availability Model to Simulate the Effects of Brush Management on Monthly Storage of Canyon Lake, South-Central Texas, 1995-2010}

By William H. Asquith and Johnathan R. Bumgarner

Prepared in cooperation with the Texas State Soil and Water Conservation Board

Scientific Investigations Report 2013-5239 


\section{U.S. Department of the Interior \\ SALLY JEWELL, Secretary}

\section{U.S. Geological Survey \\ Suzette M. Kimball, Acting Director}

\section{U.S. Geological Survey, Reston, Virginia: 2014}

For more information on the USGS — the Federal source for science about the Earth, its natural and living resources, natural hazards, and the environment, visit http://www.usgs.gov or call 1-888-ASK-USGS.

For an overview of USGS information products, including maps, imagery, and publications, visit http://www.usgs.gov/pubprod

To order this and other USGS information products, visit http://store.usgs.gov

Any use of trade, firm, or product names is for descriptive purposes only and does not imply endorsement by the U.S. Government.

Although this information product, for the most part, is in the public domain, it also may contain copyrighted materials as noted in the text. Permission to reproduce copyrighted items must be secured from the copyright owner.

Suggested citation:

Asquith, W.H., and Bumgarner, J.R., 2014, Linkage of the Soil and Water Assessment Tool and the Texas Water Availability Model to simulate the effects of brush management on monthly storage of Canyon Lake, southcentral Texas, 1995-2010: U.S. Geological Survey Scientific Investigations Report 2013-5239, 25 p., http://dx.doi. org/10.3133/sir20135239

ISSN 2328-031X (print) ISSN 2328-0328 (online) ISBN 978-1-4113-3749-7 


\section{Contents}

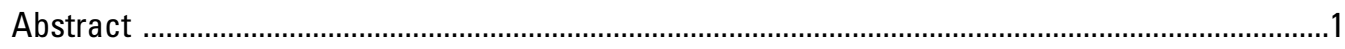

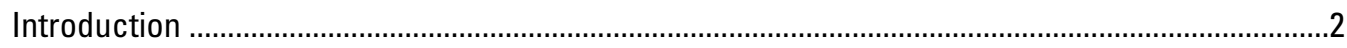

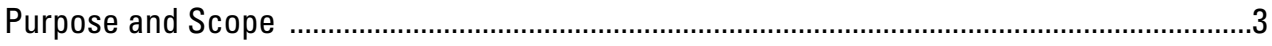

Study Area Description ....................................................................................................

Select Features and History of Canyon Lake .....................................................................

Linkage Between the Soil and Water Assessment Tool and Water Availability Model ...................7

Functional Description of the Soil and Water Assessment Tool ..............................................

Functional Description of the Texas Water Availability Model ................................................8

Linkage of the Soil and Water Assessment Tool to the Water Availability Model for the Upper Guadalupe River Watershed ...................................................................10

Conceptual Depiction of the Soil and Water Assessment Tool-Water Availability Model Linkage ............................................................................................. 10

Implemented Soil and Water Assessment Tool-Water Availability Model Linkage ...................................................................................................... 10

Linkage of the Upper Guadalupe River Soil and Water Assessment Tool and the Texas

Water Availability Model to Simulate the Effects of Brush Management ..........................13

Extensive Brush-Management Scenarios (Treatable Ashe Juniper) ....................................13

Relative (Between Scenario to Baseline) Effects of Extensive Brush-Management

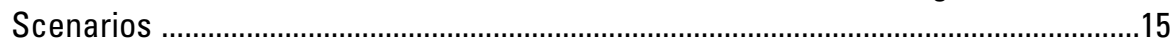

Total Inflow to Canyon Lake, 1995-2010 .....................................................................18

Monthly Storage of Canyon Lake, 1974-89 (synthetic) from Extensive BrushManagement Scenarios .............................................................................18

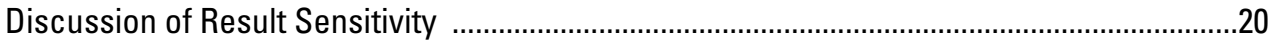

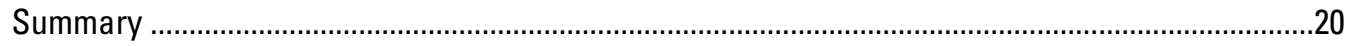

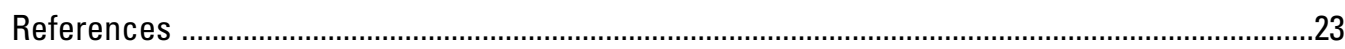

Appendixes (available online only at http://pubs.usgs.gov/sir/2013/5239/)

1. Supplemental Information and External Data Files of Total Monthly Inflow to Canyon Lake from Six Soil and Water Assessment Tool Scenarios of Extensive Brush Management for the Upper Guadalupe River Watershed, South-Central Texas, 1995-2010

2. Supplemental Information and External Data Files of Monthly Storage from the Guadalupe River Water Availability Model for Canyon Lake, South-Central Texas, 1974-89 (synthetic)

3. Supplemental Information and Computations for Select Comparisons to Results of U.S. Geological Survey Scientific Investigations Report 2012-5051 


\section{Figures}

1. Map showing location of the Guadalupe River Basin, including the upper Guadalupe River watershed study area, south-central Texas

2. Map showing location of U.S. Geological Survey streamflow-gaging station 08167500 Guadalupe River near Spring Branch, Texas, and other geographic features of the upper Guadalupe River watershed, south-central Texas

3. Map showing subbasin delineation of the upper Guadalupe River watershed by Bumgarner and Thompson (2012) with subbasin identified by number used for the Soil and Water Availability Tool and Water Availability Model linkage

4. Glossary/Nomenclature/Description of the aggregation of the Soil and Water Assessment Tool for the upper Guadalupe River watershed to create total monthly inflow to Canyon Lake, Comal County, Texas

5. Glossary/Nomenclature/Description of the linkage between the upper Guadalupe River Soil and Water Assessment Tool and Guadalupe River Water Availability Model (WAM) to create total monthly inflow to Canyon Lake, Comal County, Texas, suitable for substitution into the input-flow file of the Guadalupe River WAM

6. National Land Cover Database 2006 land-cover categories in the upper Guadalupe River watershed, south-central Texas.....

7. Graph showing relation between cumulative volume and time for total monthly inflow to Canyon Lake as simulated by Soil and Water Assessment Tool (SWAT), which includes main stem of Guadalupe River and peripheral drainage to Canyon Lake

8. Graph showing relation between monthly storage and time of Canyon Lake determined by using Soil and Water Assessment Tool (SWAT) output shown in figure 7 as (1974-89, synthetic) input to the Guadalupe River Water Availability Model (WAM) at control point 2 (CP02, U.S. Geological Survey streamflowgaging station 08167500 Guadalupe River near Spring Branch, Texas, figs. 2 and 3) for the period 1995-2010 


\section{Conversion Factors}

Inch/Pound to SI

\begin{tabular}{lcl}
\hline \multicolumn{1}{c}{ Multiply } & By & \multicolumn{1}{c}{ To obtain } \\
\hline inch (in.) & Length & centimeter $(\mathrm{cm})$ \\
foot (ft) & 2.54 & meter $(\mathrm{m})$ \\
mile (mi) & 0.3048 & kilometer $(\mathrm{km})$ \\
\hline & 1.609 & \\
\hline acre & Area & hectare $(\mathrm{ha})$ \\
square mile (square miles) & 0.4047 & square $\mathrm{kilometer}\left(\mathrm{km}^{2}\right)$ \\
\hline & 2.590 & \\
\hline gallon (gal) & Volume & liter $(\mathrm{L})$ \\
gallon (gal) & 3.785 & acre-foot $($ acre- $\mathrm{ft})$ \\
cubic foot (ft $\left.{ }^{3}\right)$ & $3.0689 \times 10^{-6}$ & cubic meter $\left(\mathrm{m}^{3}\right)$ \\
acre-foot (acre-ft) & 0.02832 & cubic hectometer $\left(\mathrm{hm}^{3}\right)$ \\
\hline & 0.001233 & \\
\hline acre-foot per year (acre-ft/year) & Flow rate & cubic meter per $\mathrm{year}\left(\mathrm{m}^{3} / \mathrm{yr}\right)$ \\
cubic foot per second (ft $3 / \mathrm{s})$ & 1,233 & cubic meter per second $\left(\mathrm{m}^{3} / \mathrm{s}\right)$ \\
gallon per day (gal/d) & 0.02832 & cubic meter per $\mathrm{day}\left(\mathrm{m}^{3} / \mathrm{d}\right)$ \\
\hline
\end{tabular}

SI to Inch/Pound

\begin{tabular}{lll}
\hline \multicolumn{1}{c}{ Multiply } & By & \multicolumn{1}{c}{ To obtain } \\
\hline millimeter (mm) & Length & \\
meter (m) & 0.03937 & inch (in.) \\
\hline
\end{tabular}

Temperature in degrees Celsius $\left({ }^{\circ} \mathrm{C}\right)$ may be converted to degrees Fahrenheit $\left({ }^{\circ} \mathrm{F}\right)$ as follows:

${ }^{\circ} \mathrm{F}=\left(1.8 x^{\circ} \mathrm{C}\right)+32$

Temperature in degrees Fahrenheit $\left({ }^{\circ} \mathrm{F}\right)$ may be converted to degrees Celsius $\left({ }^{\circ} \mathrm{C}\right)$ as follows:

${ }^{\circ} \mathrm{C}=\left({ }^{\circ} \mathrm{F}-32\right) / 1.8$

Vertical coordinate information is referenced to the North American Vertical Datum of 1988 (NAVD 88).

Horizontal coordinate information is referenced to the Texas Centric Mapping System-Albers Equal Area Projection, North American Datum of 1983 (NAD 83).

Altitude, as used in this report, refers to distance above the vertical datum. 



\title{
Linkage of the Soil and Water Assessment Tool and the Texas Water Availability Model to Simulate the Effects of Brush Management on Monthly Storage of Canyon Lake, South-Central Texas, 1995-2010
}

\author{
By William H. Asquith and Johnathan R. Bumgarner
}

\section{Abstract}

The U.S. Geological Survey (USGS), in cooperation with the Texas State Soil and Water Conservation Board, developed and applied an approach to create a linkage between the published upper Guadalupe River Soil Water Assessment Tool (SWAT) brush-management (ashe juniper [Juniperus ashei]) model and the full authorization version Guadalupe River Water Availability Model (WAM). The SWAT model was published by the USGS, and the Guadalupe River WAM is available from the Texas Commission on Environmental Quality (TCEQ). The upper Guadalupe River watershed is a substantial component of the Guadalupe River WAM. This report serves in part as documentation of a proof of concept on the feasibility of linking these two water-resources planning models for the purpose of simulating possible increases in water storage in Canyon Lake as a result of different brushmanagement scenarios.

The SWAT-WAM linkage for the upper Guadalupe River is documented with a principal objective to evaluate the distributional characteristics of the monthly water storage of Canyon Lake during selected drought conditions. Focus is on the relative evaluation of select scenarios of large-scale or "extensive" brush management within the upper Guadalupe River watershed. There are six SWAT simulations for the upper Guadalupe River watershed that include a baseline (0-percent management of treatable ashe juniper, the baseline scenario from a previous study in which no percentage of ashe juniper is numerically replaced with grassland) along with five scenarios (extensions of SWAT simulations from a previous study) of 20-, 40-, 60-, 80-, and 100-percent random (numerical) replacement of treatable ashe juniper with grasslands throughout the upper Guadalupe River watershed in south-central Texas.

SWAT is a process-based, semidistributed, waterbalance model designed to predict the effects of landscape management decisions on water yields. A watershed is subdivided into subbasins, and each subbasin is associated with a single reach on the stream network. In general a WAM, such as the Guadalupe River WAM, provides analysis of generalized water rights in a river and reservoir framework. A WAM accommodates hydrology and water usage through several input files containing water rights, watershed parameters, and naturalized streamflow time series. A WAM is generalized for application to rivers and reservoir systems, and input datasets are uniquely developed for a river basin of concern.

The extractions of SWAT output for the five extensive brush-management and baseline scenarios were offset by -21 years and, in general, the results were then mapped to the WAM input-flow file. The offset of -21 years was chosen arbitrarily for technical reasons and means that the period of monthly record 1995-2010 of the upper Guadalupe River SWAT became the synthetic period of monthly record 197489, hereinafter 1974-89 (synthetic) period, of the Guadalupe River WAM.

The relative (between scenario to baseline) effects of extensive brush-management scenarios by using the SWATWAM linkage were evaluated, and two critical intermediate results were total inflow to Canyon Lake from 1995 to 2010 and the monthly storage of Canyon Lake from 1974 to 1989 (synthetic). The first quartile or lower 25th percentile of monthly storage of Canyon Lake for the baseline scenario is 381,000 acre-feet (acre-ft) for the hereinafter 1974-89 (synthetic) period. This lower quartile was chosen for analysis for two critical purposes. First, Canyon Lake is managed with a conservation pool of about 386,200 acre-ft capacity (as recognized by the WAM) and is at or near conservation capacity about 50 percent or more of the time; further, there is intrinsic data censoring that occurs for the monthly storage distribution because Canyon Lake is at or near conservation pool elevation the majority of the time. This intrinsic censoring has the effect of creating a bounded distribution with a left or low-volume tail. Statistical assessment of the brush-management scenarios beginning with the 381,000 acre-ft censoring threshold provides readily interpretable results. Second, the quantification of brush management during periods lacking abundant rainfall, which were defined in this study as months for which Canyon Lake 
storage was below the 25 th percentile for the simulation period, are of substantial interest to water-resource managers and stakeholders in the context of water-supply enhancement.

A statistical assessment of the SWAT-WAM linkage for the low-volume tail of the distribution of monthly storage of Canyon Lake is the focus of analysis and interpretation. Drought periods for the analysis are defined as the months (consecutive or not) during which Canyon Lake is below the 25th percentile of storage (381,000 acre-ft) for the baseline scenario. Such months are referred to as being within the "Drought Quartile." The Drought Quartile is a conceptual and heuristically determined waypoint for the analysis and is not related to any administrative definition of drought by stakeholders or policy makers.

The five scenarios and the baseline scenario simulated in the upper Guadalupe River SWAT were all passed through the Guadalupe River WAM by the SWAT-WAM linkage described in this report. A comparison of the mean increase per month in reservoir storage for Canyon Lake conditioned for the Drought Quartile was made. For each of the five brush-management and baseline scenarios, the months with storage below 381,000 acre-ft were extracted. The mean monthly storages during the Drought Quartile were computed for each of the five scenarios and the baseline scenario. The mean of the baseline scenario was 376,458 acre-ft and subsequently was subtracted from the mean monthly storage during the Drought Quartile for each of the five scenarios.

The mean monthly offset storages of Canyon Lake during the Drought Quartile were 110 acre-ft (20 percent); 448 acre-ft (40 percent); 754 acre-ft (60 percent); 1,080 acre-ft (80 percent); and 1,090 acre-ft (100 percent). A particular mean was interpreted as follows: the value of 754 acre- $\mathrm{ft}$ for the 60-percent brush-management scenario implies that, on average, this scenario indicates an additional 754 acre- $\mathrm{ft}$ per month of storage in Canyon Lake relative to the baseline during the Drought Quartile. All of the five scenarios resulted in an increase on average to water supply relative to the baseline scenario during the Drought Quartile through the SWAT-WAM linkage.

\section{Introduction}

The selective or managed removal of woody plants (brush management of nonherbaceous and nonsucculent plants) in an effort to potentially increase or enhance water availability for downstream water bodies is a conservation practice being used in Texas (Natural Resources Conservation Service, 2009; Texas State Soil and Water Conservation Board, 2013). Brush management efforts attempt to enhance landscape and watershed function for purposes that include

(1) creation of desirable (native) plant communities,

(2) control of erosion, (3) improvements to water quality,

(4) enhancement of streamflow, (5) improvement of fish and wildlife habitats, (6) enhancement of forage accessibility, and (7) management of the loading of vegetative fuel attributable to wildfire generation and propagation (Natural Resources Conservation Service, 2009). Certain species of woody plants have encroached into semiarid grasslands and savannas throughout Texas (Humphrey, 1958; Archer and others, 1988; Archer, 1989). Woody plant encroachment can decrease groundwater recharge and streamflow through processes such as increases in evapotranspiration and canopy interception of rainfall. Evapotranspiration enhances soil-moisture depletion and can reduce deeper infiltration to water tables. Canopy interception of rainfall provides less water for soil moisture by enhancing evaporation (Archer and others, 1995; Dugas and others, 1998; Van Auken, 2000; Wilcox, 2002; Huxman and others, 2005; Wilcox and Thurow, 2006; Musgrove and others, 2010; Banta and Slattery, 2011).

Ashe juniper (Juniperus ashei) is a species of woody plant that has spread beyond its historical range within the understories of prairie oak motte (small stands) and within sheltered canyons in south-central Texas. Primary reasons for ashe juniper encroachment into nonhistorical landscape settings include overgrazing and fire suppression (Smeins, 1980; Fuhlendorf and others, 1996; Fuhlendorf and others, 1997). Studies of the water use of ashe juniper indicated that the species might intercept and subsequently enhance evaporation as well as generally use more water than native grasses use (Young and others, 1984; Owens, 1996; Baxter, 2009; Saleh and others, 2009; Banta and Slattery, 2011).

Brush management is primarily intended to increase water yields from managed land parcels (Natural Resources Conservation Service, 2009; Texas State Soil and Water Conservation Board, 2013). The Texas State Soil and Water Conservation Board (TSSWCB) Water Supply Enhancement Program supports brush management in Texas with a primary objective to increase streamflow delivery to downstream water-supply sources (Texas State Soil and Water Conservation Board, 2013). Brush-management feasibility studies using numerical watershed models can help identify locations of especially efficacious brush-management potential in a particular watershed.

Bumgarner and Thompson (2012) conducted a feasibility study for brush management in the upper Guadalupe River watershed by using the Soil and Water Assessment Tool (SWAT) (Arnold and others, 1998), which is a type of numerical watershed model. The study documented by Bumgarner and Thompson (2012) was done in cooperation with the TSSWCB and the Upper Guadalupe River Authority. SWAT simulations by Bumgarner and Thompson (2012) were made by using select scenarios of treatable brush management (the numerical replacement of ashe juniper with grasslands), and the possible effects of brush management on streamflow for the lower part of the upper Guadalupe River watershed were computed. Bumgarner and Thompson (2012) simulated changes in streamflow as a result of treatable brush management for 23 scenarios. 
The Water for Texas 2012 State Water Plan (Texas Water Development Board, 2011, p. 196, section 7.2.5 "Other Strategies") states that:

Brush control and other land stewardship techniques have been recommended for many areas in the western half of the state. Removing [ashe] juniper and other water consuming species has been shown in studies to restore springflow and improve surface water runoff in some cases. However, [because] water produced by this strategy during a drought when little rainfall occurs is difficult to quantify, it is not often recommended as a strategy to meet municipal needs. Brush control is recommended to supply approximately 19,000 acre-feet per year in all decades between 2010 and 2060 .

The volume of water produced by statewide brush management in Texas can be roughly estimated at about 19,000 acre-feet per year (acre-ft/year). This value is crudely derived from generalization and scaling-up of results from small-scale investigations (for example, Banta and Slattery, 2011). The 19,000 acre-ft/year volume represents only 0.2 percent of the total water volume gained by the implementation of other recommended strategies (Texas Water Development Board, 2011, p. 189 and 191, table 7.2), compared to, for example, 33.9 percent from other surface water resources and (or) projects, 16.7 percent from irrigation conservation, and 2.0 percent from groundwater desalination.

In an effort to refine estimates of water-supply enhancement potential by ashe juniper management in the upper Guadalupe River watershed, the USGS, in cooperation with the TSSWCB, developed and applied an approach to create a linkage between straightforward extensions of the upper Guadalupe River SWAT feasibility study by Bumgarner and Thompson (2012) and the Guadalupe River Water Availability Model (WAM). The Guadalupe River WAM is available from the Texas Commission on Environmental Quality (2013). The Guadalupe River WAM term used here refers to the WAM for both the Guadalupe River Basin (lower and upper basins split at Canyon Lake) and San Antonio River Basin. The upper Guadalupe River watershed is a substantial component of the Guadalupe River WAM. The primary purpose of a WAM (Wurbs, 2011) is to make predictions about the amount of water available in a stream (or lake or reservoir) at a specific control point for specific points in time. A WAM operates under a specified set of voluminous time series data and suite of parameters. In 2013, water-resource regulators and availability planners often used WAMs along with the contributions of the water-resources engineering and scientific community in Texas to evaluate the suitability of requested water rights or amendments to existing water rights.

\section{Purpose and Scope}

The primary purpose of this report is to document upper Guadalupe River watershed streamflow and Canyon Lake storage simulations obtained by linking the SWAT model documented by Bumgarner and Thompson (2012) with the Guadalupe River WAM documented by the Texas Commission on Environmental Quality (2013) (hereinafter the SWATWAM linkage). This report serves in part as documentation of a proof of concept on the feasibility of linking these two water-resources planning models to simulate possible increases in water storage in Canyon Lake as a result of different brush-management scenarios. The distributional characteristics (mean, median, lower quartile) of 16 years of simulated monthly storage of Canyon Lake were evaluated for different scenarios of large-scale or extensive brush management within the upper Guadalupe River watershed. There are six SWAT simulations including a baseline scenario and five alternative scenarios. In the baseline scenario, none of the treatable ashe juniper is replaced with grasslands (that is, 0-percent management of treatable ashe juniper, the same baseline scenario used by Bumgarner and Thompson [2012]). The five alternative scenarios replicate the SWAT simulations by Bumgarner and Thompson (2012) of 20-, 40-, 60-, 80-, and 100-percent random (numerical) replacement of treatable ashe juniper with grasslands throughout the upper Guadalupe River watershed. Text files of (1) the total monthly inflow to Canyon Lake from the baseline and five extensive brush-management scenarios emanating from the upper Guadalupe River SWAT (app. 1) and (2) the resultant monthly reservoir storage of Canyon Lake computed by the Guadalupe River WAM (app. 2) are included with the report.

The upper Guadalupe River SWAT by Bumgarner and Thompson (2012) has a period of monthly record of 1995-2010 (January through December), whereas the official Guadalupe River WAM has a period of monthly record of 1934-89 (January through December), so the time periods of the two models do not overlap. To force a time overlap (artificially link in time) in SWAT and WAM, an ad hoc postsimulation offset was chosen to move SWAT output back 21 years to temporally align the upper Guadalupe River SWAT output by respective months with the period 1974-89 of the Guadalupe River WAM. A mitigating factor for concerns of time-offset sensitivity to the results herein is that the analysis is oriented around relative as opposed to absolute magnitude numerical assessment of extensive brush-management scenarios in the upper Guadalupe River watershed.

The scope of this investigation is restricted to the full authorization version Guadalupe River WAM, which reflects specific details of water-rights allocations, permits, and other subtle circumstances by TCEQ and the water management community in Texas. In perhaps simplest terms, full authorization means that the full authorization of water rights (use) has been enabled by staff of the TCEQ. The baseline and five extensive brush-management scenarios for the upper Guadalupe River SWAT were passed into a slightly modified version of the full authorization Guadalupe River WAM. Only Canyon Lake storage was extracted from the voluminous WAM output file for the period 1974-89 (synthetic) and evaluated. The adjective synthetic will be explained in detail in the "Functional Description of the Texas Water Availability Model" section of this report. 


\section{Study Area Description}

The Guadalupe River Basin extends about 230 miles (mi) from its headwaters in the Edwards Plateau in southcentral Texas to San Antonio Bay near Tivoli, Tex., and has a total drainage area of about 10,200 square miles $\left(\mathrm{mi}^{2}\right)$. The Guadalupe River Basin and surrounding geographic features are shown in figure 1 . The study area for this investigation is the upper Guadalupe River watershed and represents about $1,432 \mathrm{mi}^{2}$ of the Guadalupe River Basin upstream from the Canyon Lake dam.

The study area encompasses parts of Bandera, Blanco, Comal, Gillespie, Kendall, Kerr, and Real Counties in southcentral Texas. The largest city in the study area is Kerrville, Tex., which had a population of 22,347 in 2010 (U.S. Census Bureau, 2011). The study area is depicted in further detail in figure 2 . The study area has a subtropical, subhumid climate characterized by hot summers and mild winters (Larkin and Bomar, 1983).

The study area is located in a karst topographic region formed by the dissolution of Cretaceous-age carbonate rocks (U.S. Geological Survey, 2006). Karst regions generally are characterized by complex and prolific groundwater-to-surfacewater interconnections, such as rapidly losing or gaining streams, sinkholes, and springs (Katz and others, 1997; Winter and others, 1998). Land cover in the upper Guadalupe River watershed is dominated by shrubland and evergreen forest (Texas Parks and Wildlife Department, 2013). Soils generally are shallow, calcareous clay and clay loam with rocky outcrops (Natural Resources Conservation Service, 2011). Elevation in the watershed ranges from about 900 to 2,400 feet (Gesch, 2007), and land slopes vary from 0 to greater than 60 percent.

Particularly pertinent to this investigation is USGS streamflow-gaging station 08167500 Guadalupe River near Spring Branch, Tex. (hereinafter the Spring Branch streamgage; see figs. 1 and 2). Three major tributaries of the Guadalupe River-Rebecca Creek, Jentsch Creek, and Tom Creek-are each downstream from the Spring Branch streamgage and are either near-upstream or direct tributaries to Canyon Lake (figs. 1 and 2). The watersheds for the three creeks are named within the Guadalupe River WAM and represent specific control points. Adjustments to parameters within the WAM for these watersheds and unnamed drainages were needed for computational consistency of water-budget equations to implement the SWAT-WAM linkage.

\section{Select Features and History of Canyon Lake}

Because Canyon Lake is the water-supply reservoir in the study area, the monthly storage of Canyon Lake and select statistical characteristics thereof are analytical endpoints of this investigation. Canyon Lake is a run-of-river reservoir formed by Canyon Dam. The impounded reservoir supplies water for municipal water supply, irrigation, and industrial uses as well as for operation of several small hydroelectric plants. At conservation pool, Canyon Lake has a published capacity of about 382,000 acre-feet (acre-ft) (Texas Water Development Board, 2001), a surface area of about $13 \mathrm{mi}^{2}$, and a shoreline of about $80 \mathrm{mi}$ (U.S. Army Corps of Engineers, 2013). Data tables for Canyon Lake within the WAM numerically recognize the conservation storage as 386,200 acre-ft (Texas Commission on Environmental Quality, 2013) as opposed to 382,000 acre-ft, and this larger value is used to minimize the number of parameters in the WAM that needed to be modified.

The U.S. Army Corps of Engineers (2013) provide an informative and relevant history of Canyon Lake,

In the early part of the 20th century, the lower Guadalupe River Basin [downstream from] the current location of Canyon Lake had been especially subject to serious flooding. [Because of] the need to lower the flooding issues, Congress authorized the construction of Canyon Lake Dam. The dam and lake [were] to serve two purposes: flood control and water conservation.

Construction of Canyon Dam began in 1958 on mile 303 of the Guadalupe River [upstream from the mouth]. The dam was finish[ed] in 1964 and water impoundment began. The lake was dedicated in 1966. The lake filled to conservation pool level by 1968. Canyon Dam controls floods originating on the [approximately] 1,432 square miles of drainage above the dam. Flood protection is provided to [approximately] 157,250 acres of land downstream from the dam.

The high canyons of the upper Guadalupe have a channel capacity of 40,000-50,000 cubic feet per second. The channel on the lower Guadalupe River has a capacity of only 13,000-30,000 cubic feet per second. [The lowering of channel capacity by the geomorphic features of the channel in the upper and lower watersheds is] the cause of prior flood events before the dam construction.

At conservation pool level Canyon Lake has a capacity of 382,000 acre-feet. At flood control pool level[,] the lake has an additional capacity of 346,000 acre-feet making total storage [approximately] 728,400 acre-feet. 


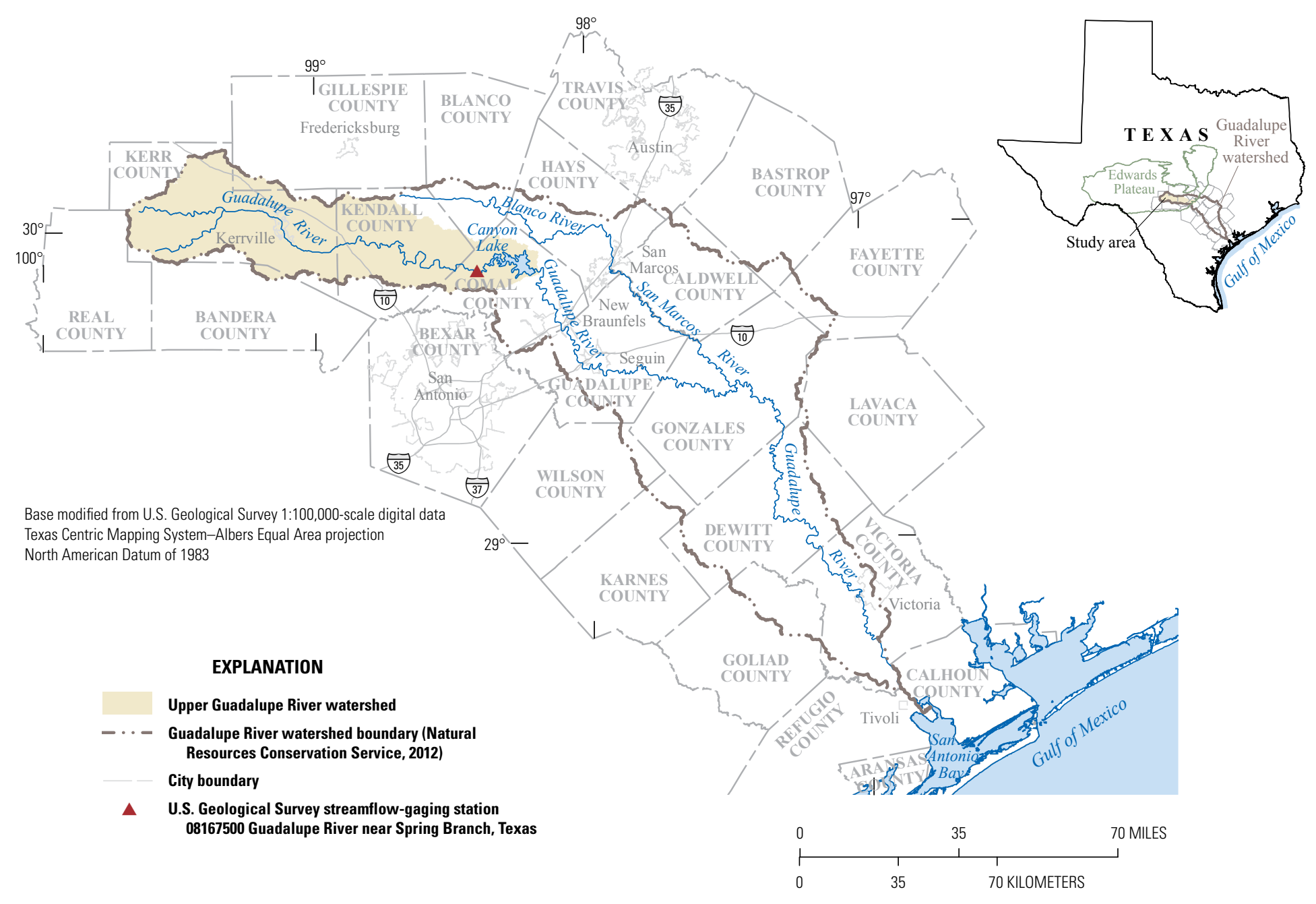

Figure 1. Location of the Guadalupe River Basin, including the upper Guadalupe River watershed study area, south-central Texas (Bumgarner and Thompson, 2012). 


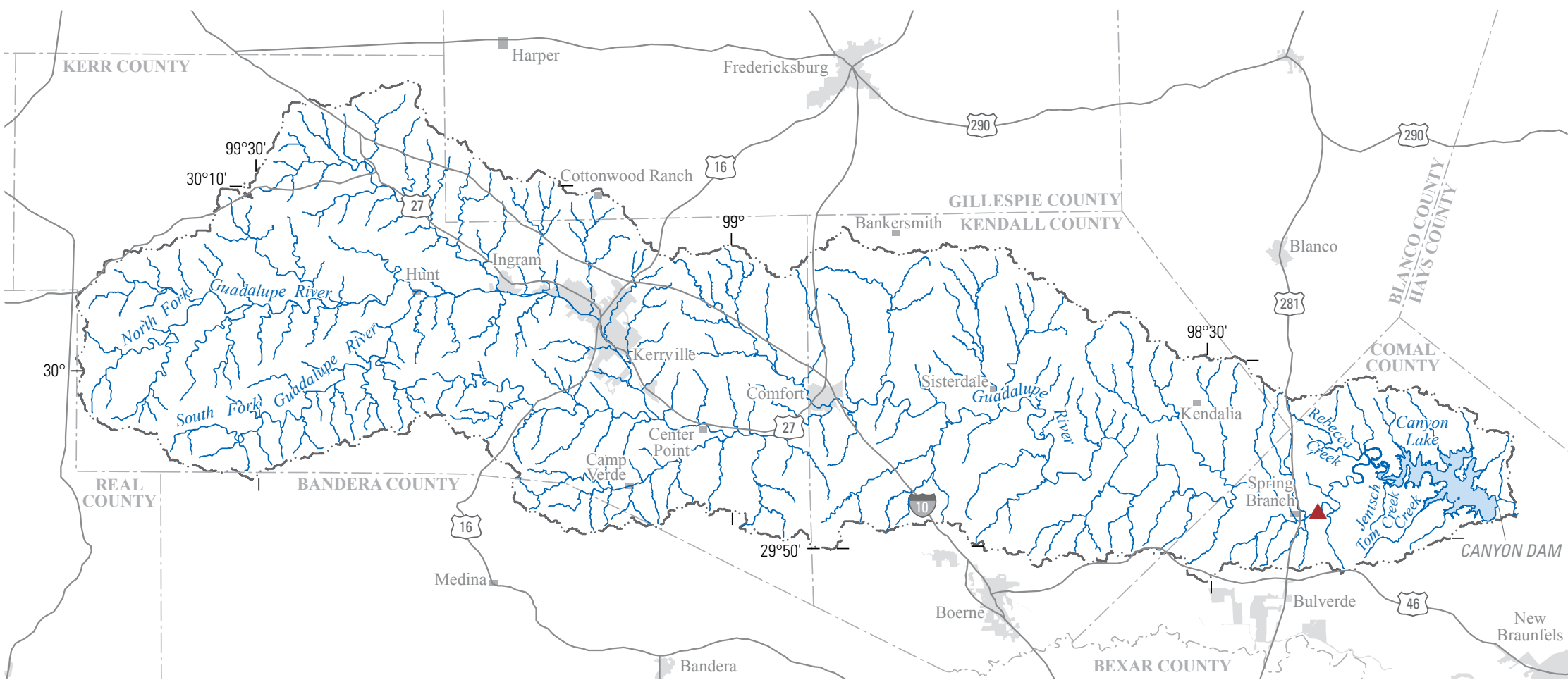

Base modified from U.S. Geological Survey 1:100,000-scale digital data Texas Centric Mapping System-Albers Equal Area projection North American Datum of 1983

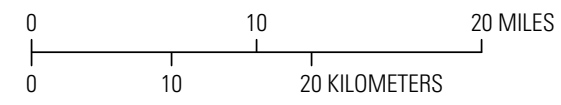

\section{EXPLANATION}

- -. - Upper Guadalupe River watershed boundary

U.S. Geological Survey streamflow-gaging station 08167500 Guadalupe River near Spring Branch, Texas

Figure 2. Location of U.S. Geological Survey streamflow-gaging station 08167500 Guadalupe River near Spring Branch, Texas, and other geographic features of the upper Guadalupe River watershed, south-central Texas (modified from Bumgarner and Thompson, 2012, fig. 2). 
The Texas Water Development Board (2001, table 1) performed a volumetric survey for Canyon Lake. The conservation storage values by year reported by the Texas Water Development Board (2001, table 1) were 386,200 acre-ft in 1952, prior to dam construction; 382,000 acre- $\mathrm{ft}$ in 1972; and 378,852 acre-ft in 2000. The general decrease in storage can be attributed to sedimentation. The 2001 volumetric survey of Canyon Lake reports that a 0.1 -foot change in elevation of the water surface is associated with a change of storage of about 828 acre-ft $(381,329-380,501$ acre-ft) at storage conditions around 381,000 acre- $\mathrm{ft}$, and these storage conditions represent an approximate $13-\mathrm{mi}^{2}$ surface area (Texas Water Development Board, 2001, p. 18, appendix A). The 381,000-acre-ft storage condition and the 828 acre-ft per 0.1 -foot change have prominence for interpretation of results herein.

\section{Linkage Between the Soil and Water Assessment Tool and Water Availability Model}

This section is divided into two parts: (1) the previously developed SWAT and WAM models are described, and (2) the linkage between SWAT and WAM is described. Each part provides a functional description of the independent and application-specific models (SWAT and WAM) germane to this investigation. Background information and a functional description of SWAT are provided based on the description by Bumgarner and Thompson (2012) followed by a functional description of the Guadalupe River WAM. Specific input and output files of the Guadalupe River WAM are identified along with a description of the functional purpose of each file of the WAM.

\section{Functional Description of the Soil and Water Assessment Tool}

This section is modified from Bumgarner and Thompson (2012, p. 6). SWAT (Arnold and others, 1998) is a processbased, semidistributed water-balance model designed to predict the effects of landscape management decisions on water, sediment, and agricultural chemical yields. Within SWAT, a watershed is subdivided into subbasins, and each subbasin is associated with a single reach on the stream network. As summarized by Garcia (2009), each subbasin is further divided into hydrologic response units (HRUs) that consist of unique combinations of land cover, soil characteristics, land slope, and land-management criteria. Processes including but not limited to surface runoff, evapotranspiration, base flow, channel transmission losses, plant life cycles, nutrient cycling, and constituent transport can be simulated for each HRU. The numerical aspects of these processes are determined by the process-related parameter values uniquely defined for each HRU (Arnold and others, 1998; Garcia, 2009; Neitsch and others, 2011a).

During model development, default values are assigned to the model parameters by the modeling software based on the unique HRU characteristics. The simulated water volumes are aggregated within their corresponding subbasins, are allocated to the subbasin reach, and exit a subbasin through outlets along the stream network. Algorithms in SWAT account for watershed and in-stream processes and include routing of streamflows from upstream subbasins downstream to watershed outlets (Arnold and others, 1998; Garcia, 2009; Neitsch and others, 2011a).

Model output includes streamflow for any subbasin outlet and specific aggregations thereof. The HRUs are delineated in the SWAT model from the input data and user-specified parameters. The analyst assigns default parameter values and then completes the calibration process by adjusting selected parameters to achieve a level of quantified uncertainty and sensitivity (Bumgarner and Thompson, 2012). A complete description of SWAT and simulated processes are identified in Neitsch and others (2011a).

The hydrologic component of SWAT uses a runoff curvenumber $(\mathrm{CN})$ equation described by the Natural Resources Conservation Service (Soil Conservation Service, 1986). The $\mathrm{CN}$ equation is heuristically based and relates runoff potential to land-cover and soil-type characteristics. A high $\mathrm{CN}$ near the upper limit of 100 translates into substantial runoff, whereas a low $\mathrm{CN}$ near the lower limit of 0 translates into almost no runoff. For example, forested land cover, such as ashe juniper, has a lower $\mathrm{CN}$ than grasslands and produces less runoff (Soil Conservation Service, 1986).

In an empirical study of rainfall and runoff for small watersheds in Texas, Thompson and others (2003) provided a critical review of $\mathrm{CN}$ applications for high-magnitude streamflow computations that are oriented around the needs of transportation infrastructure design engineers. The $\mathrm{CNs}$ are used within regression equations by Asquith and Roussel (2007) for estimation of initial abstraction and constant loss parameters for rainfall-runoff modeling involving the unit hydrograph in applicable areas of Texas.

Daily CN values for SWAT application in Bumgarner and Thompson (2012) and in this investigation were calculated in the model as a function of plant evapotranspiration instead of the standard or default computation in SWAT. The default computation is a function of soil moisture (Neitsch and others, 2011b). Daily CNs, when calculated as a function of soil moisture, have a tendency to overestimate runoff (Neitsch and others, 2011b) in watersheds with shallow soils. The watershed of the upper Guadalupe River watershed generally has shallow soils (Natural Resources Conservation Service, 2011) and substantial spatial and temporal variation in soil moisture. 
The variation of SWAT used for this investigation was the program SWAT2009. exe (revision 445). The upper Guadalupe River SWAT encompasses the period of monthly record 1995-2010 (January through December). In general, the SWAT program can be executed from within a geographic information system (GIS), which incorporates spatially distributed data. For this investigation, ArcGIS 9.3.1 (Environmental Systems Research Institute, Inc., 2009) and the ArcGIS extension ArcSWAT (version 2009.93.5) (Winchell and others, 2010) were used to execute SWAT. Description of SWAT and simulations presented in this report can be conceptually replicated by following the model-development steps described in the user manual of ArcSWAT (Winchell and others, 2010).

A complete description of the upper Guadalupe River SWAT can be found in Bumgarner and Thompson (2012). The subbasins and their respective identification numbers are the same as in the Bumgarner and Thompson (2012) identification scheme (fig. 3). It is important to note that the model reaches in figure 3 represent a trimmed stream network compared to the streams shown in figure 2. The trimmed stream network reflects the conceptual reaches within SWAT. Each subbasin has a reach associated within it, and the reach has the same number as the subbasin. The subbasins including and downstream from the Spring Branch streamgage (fig. 3) require special attention for the SWAT-WAM linkage and are identified by a red color scheme in the figure. Two reaches within Subbasins 85 and 58 are pertinent.

\section{Functional Description of the Texas Water Availability Model}

Wurbs and Lee (2011, p. 451) provided a concise description of the WAM purpose and framework. Wurbs and Lee stated:

The Texas Commission on Environmental Quality (TCEQ), in collaboration with the Texas water management community, maintains a Water Availability Modeling (WAM) System used in the administration of the state's water rights permit system, regional and statewide planning, and other activities (Wurbs, 2004). The TCEQ WAM System consists of the generalized Water Rights Analysis Package (WRAP) river/reservoir system water management simulation model and WRAP hydrology and water rights input files for the 23 river basins of Texas. The WRAP modeling system is generalized for application to river/reservoir systems located anywhere in the world, with input datasets being developed for the particular river basin of concern. For WRAP simulation studies assessing water availability and supply reliability in Texas, readily available TCEQ WAM System data files are altered as appropriate to reflect proposed water management plans of interest. These plans could involve changes in water use or reservoir system operating practices, construction of new facilities, or other water management strategies.

The Guadalupe River WAM encompasses the period of January through December monthly streamflow records during 1934-89. For this investigation, only the monthly computation steps of the WAM were used; daily computations were not used. The entire 1934-89 period was used for each model run of the WAM. Three files of the WAM are germane to this investigation. The file names, where gsa means Guadalupe-San Antonio River Basins and run3 has no special interpretation for this investigation and reflects nomenclature by TCEQ, are gsa_run3. inf (inflow-text file), gsa_run3.dis (text file containing watershed drainage areas and numerous other parameters that are not germane to this investigation), and gsa_run3. out (text file created by the WAM software that contains the modeled monthly reservoir storage of Canyon Lake). To accomplish the SWATWAM linkage objective of this investigation, only slight modifications to the WAM file gsa_run3.dis were made; the modifications were restricted to four drainage-area parameters of the Guadalupe River WAM as described in the section of this report titled "Linkage of the Soil and Water Assessment Tool to the Water Availability Model for the Upper Guadalupe River Watershed."

SWAT output files were extracted for five extensive brush-management and baseline scenarios and offset by -21 years. The offset of -21 years means that the period of monthly streamflow record during 1995-2010 of the upper Guadalupe River SWAT becomes the synthetic period of monthly streamflow record during 1974-89, hereinafter the 1974-89 (synthetic) period, for the Guadalupe River WAM. The results then are "mapped to" (a term that evokes the mathematical notation that was used) the WAM input-flow file. The total monthly inflows to Canyon Lake are the most salient results of SWAT simulations and are available as text files for download as described in appendix 1 from the on-line version of this report. The total monthly inflow files provided in appendix 1 show the 1995-2010 period because this is the actual, or true, time period of input data, calibration, and simulations by the upper Guadalupe River SWAT previously calibrated by Bumgarner and Thompson (2012). 


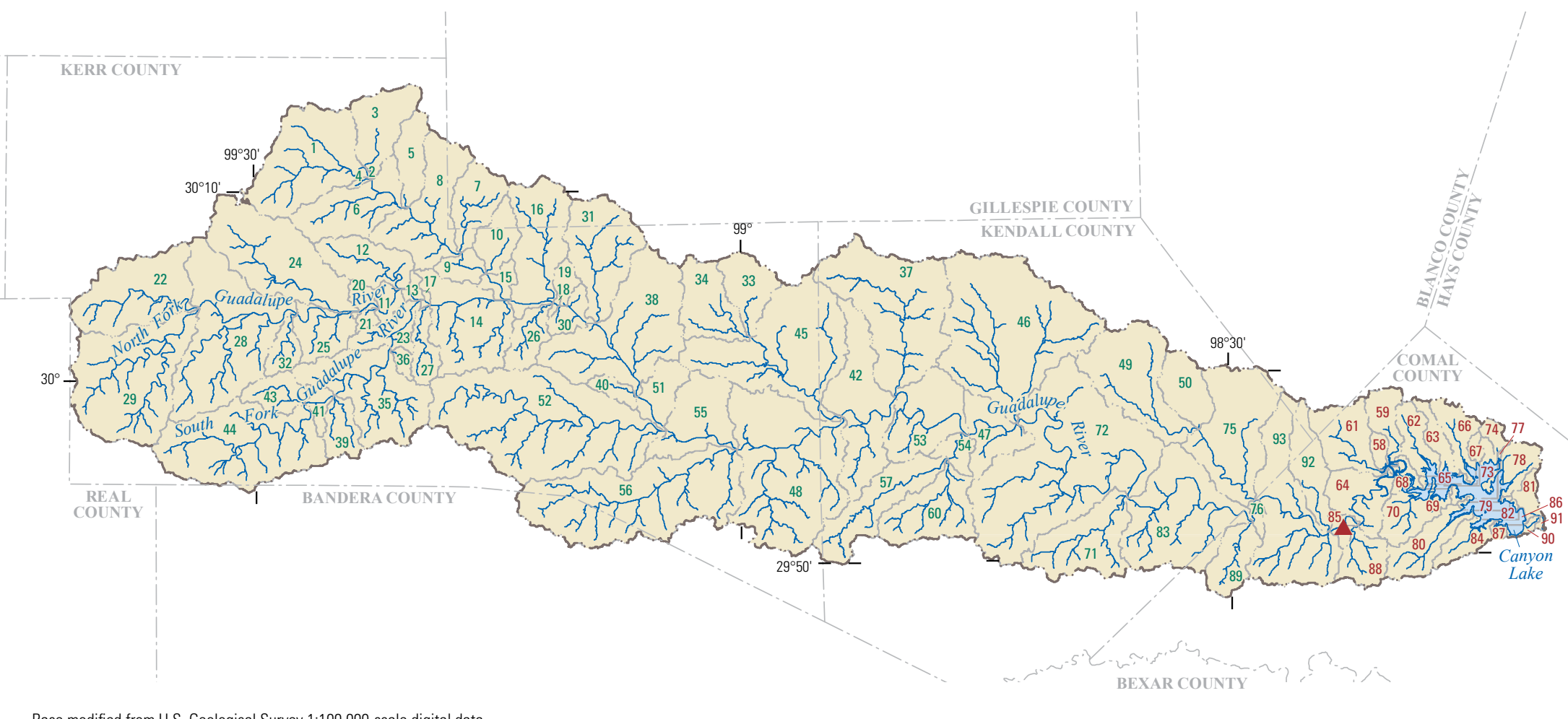

Base modified from U.S. Geological Survey 1:100,000-scale digital data Texas Centric Mapping System-Albers Equal Area projection North American Datum of 1983

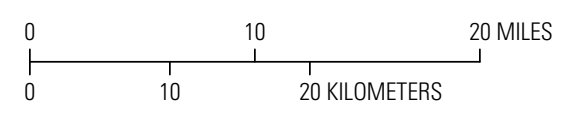

\section{EXPLANATION}

72 or 64 Model subbasin and numbers by Bumgarner and Thompson (2012 where green numbers are not germane and red numbers are described in figure 4

- - - Upper Guadalupe River watershed boundary

Bumgarner and Thompson (2012) stream reach

- U.S. Geological Survey streamflow-gaging station 08167500 Guadalupe River near Spring Branch, Texas

Figure 3. Subbasin delineation of the upper Guadalupe River watershed by Bumgarner and Thompson (2012) with subbasin identified by number used for the Soil and Water Availability Tool and Water Availability Model linkage (modified from Bumgarner and Thompson, 2012, fig. 3). 


\section{Linkage of the Soil and Water Assessment Tool to the Water Availability Model for the Upper Guadalupe River Watershed}

\section{Conceptual Depiction of the Soil and Water Assessment Tool-Water Availability Model Linkage}

Separate discussions of (1) the conceptual design and preprocessing (this section) and (2) presetup (next section titled "Implemented Soil and Water Assessment Tool-Water Availability Model Linkage") are provided. The conceptual design establishes the necessary preprocessing of SWAT output files in the context of the hierarchical structure of SWAT output and the format required for WAM input. The principal objective of the preprocessing of SWAT output is to aggregate or combine the streamflows (reach files) or subbasin output into a total monthly inflow to Canyon Lake in acrefeet and format the streamflow aggregation into a format that is compatible with subsequent executions of the Guadalupe River WAM.

Two major plain-text output files result from a SWAT simulation: (1) reach streamflow $(\mathrm{RCH})$ files and (2) subbasin output flow (SUB) files. Each output file type (RCH and SUB files) for the upper Guadalupe River SWAT are individually voluminous for a given brush-management scenario. The RCH and SUB nomenclature for this investigation parallels the watershed subdivisions by Bumgarner and Thompson (2012).

Monthly streamflow totals extracted from the SWAT model for the part of the Guadalupe River watershed monitored by the Spring Branch streamgage (Bumgarner and Thompson, 2012) were used as the initial input for calibration purposes. The Spring Branch streamgage is coincident with Reach 85 (RCH85) of the SWAT model, which resides in Subbasin 85 (SUB85), and RCH85 values for a single simulation scenario were extracted from the $\mathrm{RCH}$ file by using a script written in the Perl programming language.

The streamflow in RCH58 must equate to the streamflow in RCH85 (as measured at the Spring Branch streamgage) when RCH85 streamflow is added to the streamflows from subbasins SUB61, SUB64, and SUB88 of the SWAT (Bumgarner and Thompson, 2012). A diagram and additional description are shown in figure 4 . The SUB values for a single simulation scenario for subbasins SUB61, SUB64, and SUB88 were extracted from the SUB file, and streamflow in RCH85 subsequently was summed by using a second Perl programming language script to process SUB files. The reliability of the two Perl scripts was confirmed by comparing the summation RCH85 + SUB61 + SUB64 + SUB88 streamflows (results not reported here) to extracted streamflow in RCH58; numerical congruence was independently verified by using spreadsheet computations (not reported here). The two Perl scripts also provided for additional extractions from SWAT output files that combined the data to create total upstream inflow within the Guadalupe River into Canyon Lake as well as the peripheral inflow to Canyon Lake. Additional Perl scripts executing other Perl scripts provided for various batch-processing operations of SWAT output for the five scenarios and the baseline scenario.

The summation of streamflow in RCH58 and SUB59 provided the total upstream inflow into Canyon Lake that is provided by only the Guadalupe River. The RCH58 + SUB59 summation was then added to the summation of all subbasins providing peripheral inflow to Canyon Lake (fig. 3). The peripheral inflow, as recognized by Bumgarner and Thompson (2012, fig. 8), is represented by Delineation 23 ("brush-management subbasin" in Bumgarner and Thompson [2012] nomenclature) and is the summation of outflow from 21 peripheral subbasins. The 21 subbasins (fig. 3) are sequentially enumerated in the fourth bulleted item in figure 4 . The Delineation 23 total, which is the summation of the 21 subbasins of Bumgarner and Thompson (2012), when added to total upstream inflow (RCH58 + SUB59) becomes the total monthly inflow into Canyon Lake. The total inflow files (app. 1) of post-SWAT processed files are in a format that replicates the format required for the WAM input-flow file titled gsa_run3.inf, although the labels for the period 19952010 (January through December) were retained for the files in appendix 2. Lastly, and critical for linkage to the Guadalupe River WAM, the total inflow by month for the period 19952010 was passed into the WAM, through the WAM control point coincident with the Spring Branch streamgage.

\section{Implemented Soil and Water Assessment Tool- Water Availability Model Linkage}

Specific notation pertaining to nomenclature of the WAM is required and linked to various record identifiers in the Guadalupe River WAM (Wurbs, 2011; Texas Commission on Environmental Quality, 2013) by cross-reference to figure 4. Visual referencing for the WAM components is available by using GIS data files for the Guadalupe River WAM available from Texas Commission on Environmental Quality (2013). The GIS data files were consulted to determine record identifiers to build the watershed and control point hierarchy and thus guide modifications to the gsa_run3.dis file of the Guadalupe River WAM.

The watershed and control hierarchy and additional description of the SWAT-WAM linkage are shown in figure 5. The parts of WAM parameters requiring slight modification to support linkage to SWAT are shown with an objective to achieve the slightest modification (only four drainage arearelated parameters altered) possible to the otherwise officially accepted Guadalupe River WAM. Drainage areas and their respective influences on WAM operation are important and especially noted in figure 5 . 


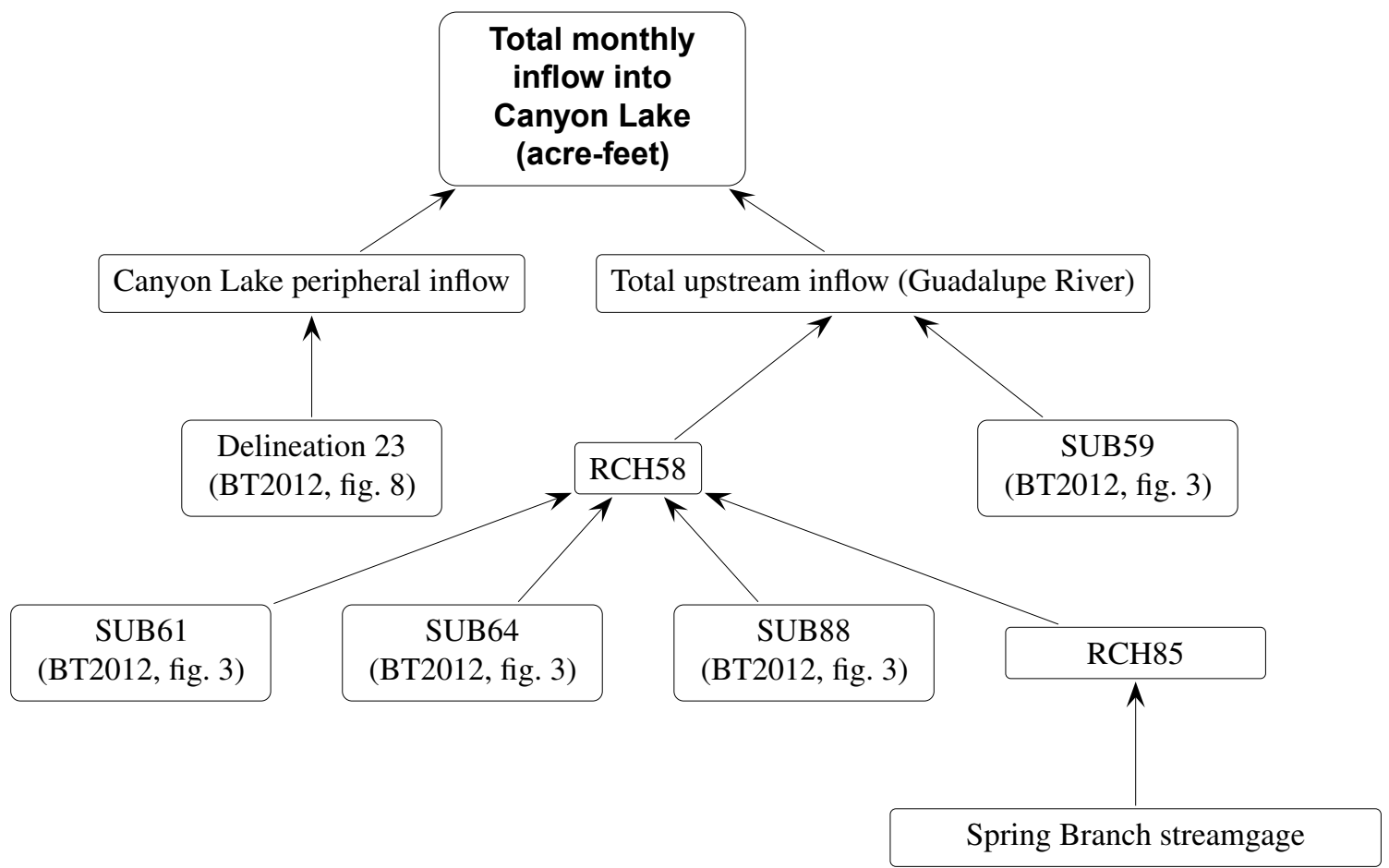

\section{Glossary/Nomenclature/Description:}

- BT2012-Bumgarner and Thompson (2012);

- Soil and Water Assessment Tool (SWAT) generates two types of output files: reach (RCH) and subwatershed (SUB). These are aggregated (summed) in the pathway of the above diagram to create total monthly inflow to Canyon Lake for substitution in the Water Availability Model input-flow file gsa_run3.inf;

- Streamflow direction is represented by arrow heads;

- Delineation 23 (Bumgarner and Thompson, 2012, fig. 8) is composed of subwatersheds (Bumgarner and Thompson, 2012, fig. 3): SUB62, SUB63, SUB65, SUB66, SUB67, SUB68, SUB69, SUB70, SUB73, SUB74, SUB77, SUB78, SUB79, SUB80, SUB81, SUB82, SUB84, SUB86, SUB87, SUB90, and SUB91. Delineation 23 may be generally thought of as peripheral flow to Canyon Lake.

- The SWAT model produces stream reach $(\mathrm{RCH})$ records for the main channel within each same numbered SUB such as RCH85. This reach represents the same location as U.S. Geological Survey streamflow-gaging station 08167500 Guadalupe River near Spring Branch, Texas ("Spring Branch streamgage"). RCH85 represents aggregated streamflow for all subwatersheds upstream from this streamgage. These subwatersheds are not enumerated here nor are they shown in figure 3, but they are represented in Bumgarner and Thompson (2012, fig. 2). RCH58 is the reach having summation of SUB61, SUB64, SUB88, and RCH85.

Figure 4. Glossary/Nomenclature/Description of the aggregation of the Soil and Water Assessment Tool for the upper Guadalupe River watershed to create total monthly inflow to Canyon Lake, Comal County, Texas. 


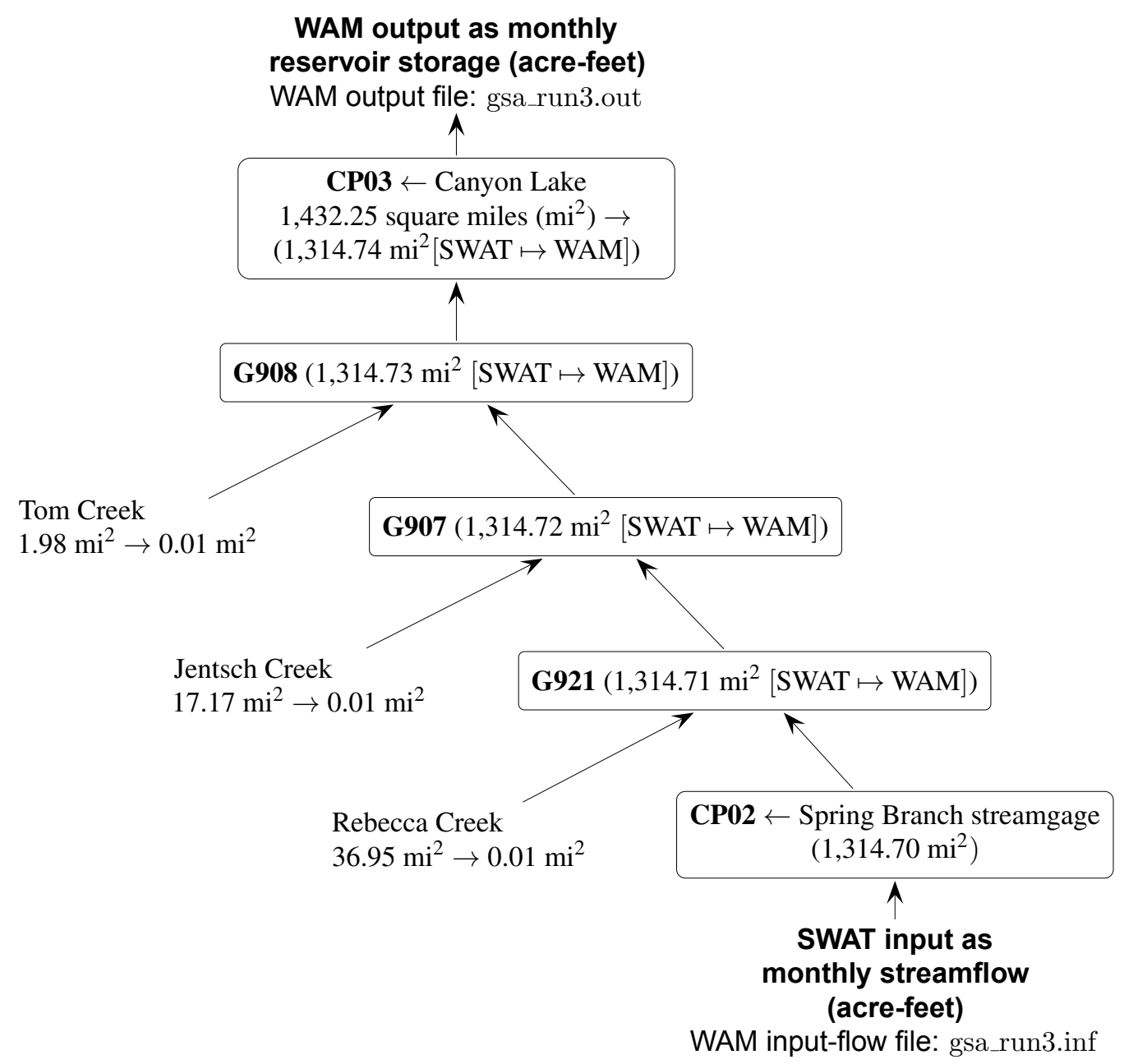

\section{Glossary/Nomenclature/Description:}

- Water Availability Model (WAM) with output in text file gsa_run3.out, Soil and Water Assessment Tool (SWAT) output substituted into WAM input text file gsa_run3.inf;

- Arrow heads represent direction of streamflow, solid lines represent the main stem of the Guadalupe River, and dashed lines are tributaries within the WAM;

- "[SWAT $\mapsto$ WAM]" is to read "SWAT mapped to WAM" through the drainage area $(D A)$ modification and the $D A$ within parentheses are those used for the WAM application described in this report;

- WAM control points $(\mathrm{CP})$ are identified with a left arrow $(\leftarrow)$ indicating that the geographic feature or place name corresponds to the control point. CP02 is U.S. Geological Survey streamflow-gaging station 08167500 Guadalupe River near Spring Branch, Texas ("Spring Branch streamgage");

- Tributary confluences by WAM creek name and WAM confluence numbers are G908, G907, and G921; and

- Right arrows $(\rightarrow)$ indicate that the tributary DAs were converted to 0.01 square miles $\left(\mathrm{mi}^{2}\right)$ for the purpose of linking the SWAT model output to the WAM input. The DAs are set within the WAM gsa_run3.dis text file by the subordinate "WP records." Conceptually, there are three recognized tributaries and unnamed aggregated peripheral inflow to Canyon Lake. The small DA increase from GP908 through to CP03 hence "virtually" turns off the ungaged watershed algorithms in the WAM without further modification of established parameters in the WAM-in total, the DA increase from CP02 through to CP03 is $0.04 \mathrm{mi}^{2}$.

Figure 5. Glossary/Nomenclature/Description of the linkage between the upper Guadalupe River Soil and Water Assessment Tool and Guadalupe River Water Availability Model (WAM) to create total monthly inflow to Canyon Lake, Comal County, Texas, suitable for substitution into the input-flow file of the Guadalupe River WAM. 
The diagram in figure 5 shows that the starting point of the linkage is control point number 2 (CP02), which is coincident with the Spring Branch streamgage. SWAT total inflow files (app. 1) are passed through CP02. To maintain appropriate streamflow mass (quantity), it was necessary to modify the WAM for four watershed property parameter input values representing four locations downstream from $\mathrm{CP} 02$ to control point 3 (CP03); $\mathrm{CP} 03$ is the identifier for Canyon Lake in the WAM parameter file gsa_run3.dis.

There are three named tributaries in the Guadalupe River WAM encompassing most of the drainage area to Canyon Lake downstream of the Spring Branch streamgage - Rebecca Creek (G921 control point), Jentsch Creek (G907 control point), and Tom Creek (G908 control point) - as well as a remaining unnamed aggregate drainage area to Canyon Lake. The remaining unnamed drainages are the numerous small and peripheral watersheds directly flowing into Canyon Lake as described in the section titled "Conceptual Depiction of the Soil and Water Assessment Tool-Water Availability Model Linkage." These four watersheds are turned off by deliberate adjustment of the drainage areas in the WAM parameter file gsa_run3.dis. The deliberate adjustment is made to have the WAM turn off the WAM-specific computations of contributing streamflow because SWAT simulations already account for the water. The change in drainage area, because each of the four watersheds is numerically encountered during WAM execution, was chosen as $0.01 \mathrm{mi}^{2}$ to be vanishingly small for the SWAT-WAM linkage. To clarify, each of the four watersheds recognized by, that is, incorporated into, the WAM between $\mathrm{CP} 02$ and $\mathrm{CP} 03$ was adjusted to have a drainage area of only $0.01 \mathrm{mi}^{2}$ instead of the real-world increase in drainage area because each tributary converges with the main stem of the Guadalupe River. To clarify, SWAT numerically accommodates the four ungaged watersheds, and the WAM uses a type of apportioning based in part on Spring Branch streamflow (CP02); therefore, it is critical to effectively turn the four watersheds off within the WAM to maintain appropriate streamflow mass.

Further clarification is sought to avoid potential confusion because the WAM uses a cumulative drainage area as each successive input (control point, permit [water use] point, or tributary) enters the Guadalupe River main stem. The drainage areas listed within the parentheses in figure 5 are the precise drainage areas used in a modified version of the gsa_run3.dis parameter file of the WAM. The reassignment of drainage areas by an increase of $0.01 \mathrm{mi}^{2}$ per tributary was chosen instead of zero to guard against potential division by zero errors or other potential problems of WAM execution. When the tributaries are numerically small, as seen in the complex WAM water-budget accounting algorithms, the WAM becomes suitable for passage of total monthly inflow for Canyon Lake from the upper Guadalupe River SWAT through the Spring Branch streamgage (CP02). The modification of intervening drainage areas from $\mathrm{CP} 02$ to $\mathrm{CP} 03$ is conceptually easiest to explain as opposed to more complicated and errorprone steps to turn off ungaged watershed computations within
WAM, such as the drainage area ratio method (Asquith and others, 2006) that is a form of streamflow apportionment by ratios of watershed areas.

\section{Linkage of the Upper Guadalupe River Soil and Water Assessment Tool and the Texas Water Availability Model to Simulate the Effects of Brush Management}

\section{Extensive Brush-Management Scenarios (Treatable Ashe Juniper)}

Five scenario land-cover datasets were selected to evaluate the relative (between scenario to baseline) potential for extensive brush management for water-supply enhancement in the upper Guadalupe River watershed. The baseline scenario considered for this investigation (0-percent ashe juniper management in which no ashe juniper is replaced with grassland, fig. 6) is the same as the nontreatment calibration scenario of Bumgarner and Thompson (2012). Modified datasets from Bumgarner and Thompson (2012) were generated by randomly replacing $20,40,60,80$, and 100 percent of the treatable ashe juniper (ashe juniper that could potentially be replaced with grassland through extensive brush management). The adjective "extensive" is deliberately chosen because the numerical conversion of treatable ashe juniper to grassland is on a scale much larger than individually considered in any of the 23 brush-management scenarios considered by Bumgarner and Thompson (2012). The HRUs were generated for the upper Guadalupe River SWAT simulations for this investigation by using the modified landcover datasets. Although spanning 16 years (1995-2010) of simulation, SWAT scenarios of brush management did not consider potential ashe juniper regrowth during the simulation period because doing so was beyond the scope of this investigation.

The National Land Cover Database (NLCD) 2006 (Fry and others, 2011) was modified to simulate the numerical replacement of 20,40,60,80, and 100 percent of the treatable ashe juniper within the upper Guadalupe River watershed with grasslands. Four NLCD 2006 categories were chosen to represent areas that might contain ashe juniper: (1) Deciduous Forest, (2) Evergreen Forest, (3) Mixed Forest, and (4) Shrubland (fig. 6). Because the NLCD 2006 categories do not explicitly identify vegetation types, a second dataset with more detailed categories of vegetation was required in a defensible attempt to isolate the treatable ashe juniper. Bumgarner and Thompson (2012) provided extensive discussion leading to the phrase "treatable ashe juniper" for the upper Guadalupe River watershed. 


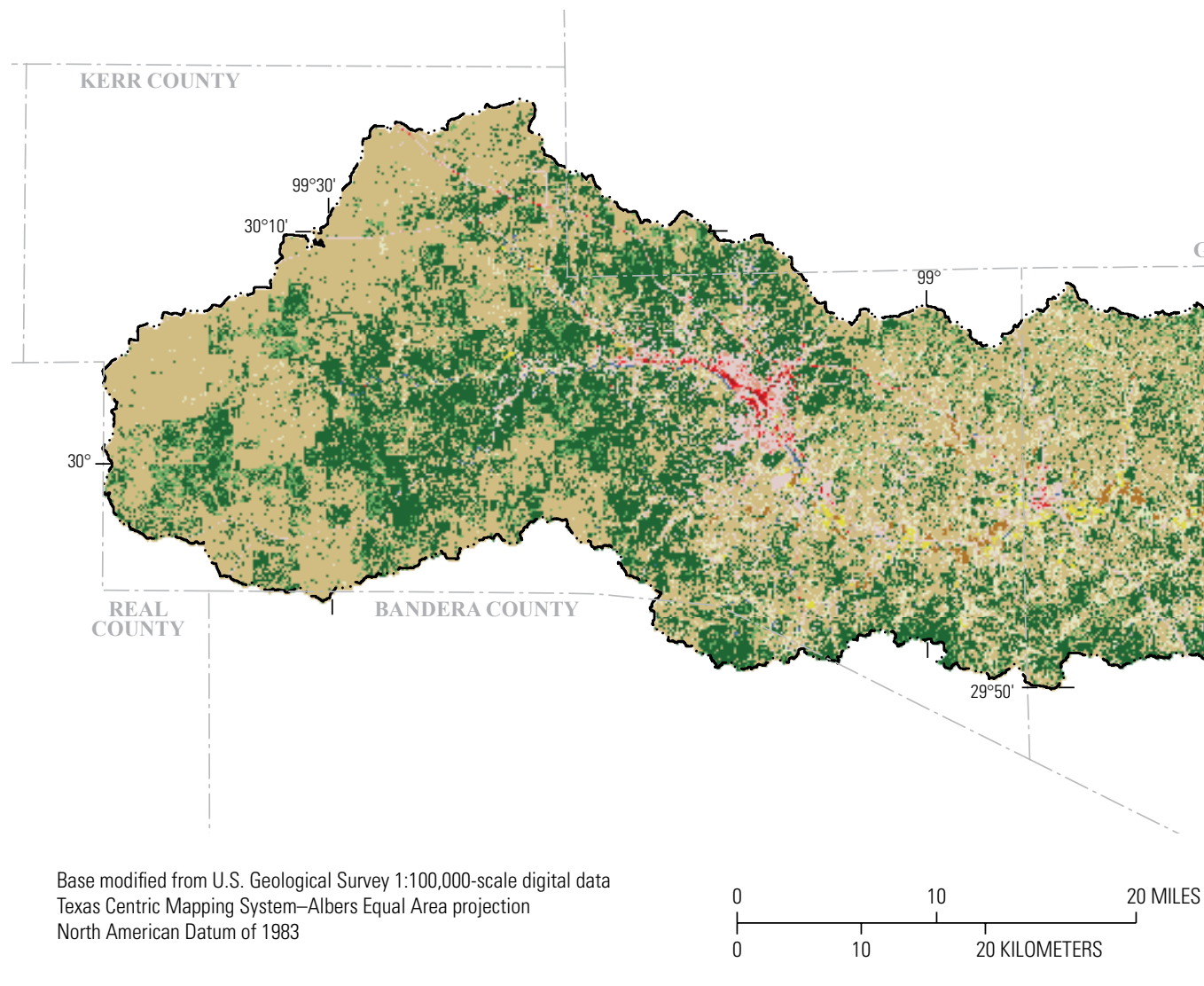

Land-cover categories for which ashe juniper was numerically converted to grassland are deciduous forest, evergreen forest, mixed forest, and shrubland and are shown in the explanation. A summary of treatable ashe juniper acreages, as numerically reported to the acre by the geographic information system that created the datasets of five extensive brush-management scenarios. These datasets contributed to the Soil Water Assessment Tool (SWAT) simulations. The acreages and percent of total upper Guadalupe River watershed area (918,793 acres) for the scenarios are:

\begin{tabular}{|c|c|c|}
\hline Baseline: & 0 acres & ( 0 percent) \\
\hline 20 percent: & 39,487 acres & ( 4.3 percent) \\
\hline 40 percent: & 78,981 acres & ( 8.6 percent) \\
\hline 60 percent: & 118,482 acres & (12.9 percent) \\
\hline 80 percent: & 157,991 acres & (17.2 percent) \\
\hline 100 percent: & 197,504 acres & (21.5 percent) \\
\hline
\end{tabular}

\section{EXPLANATION}

\section{Land-cover category}

Open water

Developed, open space

Developed, low intensity

Developed, medium intensity

Developed, high intensity

Barren land

Deciduous forest

Figure 6. National Land Cover Database 2006 land-cover categories in the upper Guadalupe River watershed, south-central Texas (modified from Bumgarner and Thompson, 2012, fig. 6). 
Replicating the SWAT simulation approach documented by Bumgarner and Thompson (2012), the geodatabase files for the Texas Parks and Wildlife Department Texas Ecological Systems Classification Project (TESCP) (Texas Parks and Wildlife Deparment, 2013). The digital files for the TESCP can be acquired from the Geographical Information System Laboratory of the Texas Parks and Wildlife Department.

Additional land-cover information was needed because TESCP has 43 ecological system categories in the study area, and ashe juniper was identified as present in 13 of the 43 categories. The 13 categories with ashe juniper were evaluated on the basis of TESCP ecological-system descriptions. Categories in which ashe juniper was listed as one of the dominant vegetation types in the category description (except where associated with riparian zones [streamside corridors] or steep slopes) were selected for use in the brush-management scenarios described in this report. The categories dominated by ashe juniper that also were associated with riparian zones or steep slopes were not converted to grassland for the brush-management simulations and instead were classified as untreatable areas because, as explained by Afinowicz and others (2005), actual field applications are unlikely to replace ashe juniper with grasslands in these areas. Areas of steep slope were identified in the TESCP nomenclature as land cover on slopes greater than 20 percent and less than 100 percent.

For Bumgarner and Thompson (2012) and for this investigation, there were three TESCP categories chosen to represent the location of ashe juniper to be replaced with grassland for the brush-management simulations. The common names for the three TESCP categories are Edwards Plateau: Ashe Juniper Motte and Woodland; Edwards Plateau: Ashe Juniper and Live Oak Shrubland; and Native Invasive: Ashe Juniper Shrubland. The two TESCP land-cover class names are Juniper Forest and Juniper Shrubland, and the three TESCP location categories are in about 23 percent of the upper Guadalupe River watershed when the aspect of treatability is considered. The percentage of 23 nearly matches the average of 22 percent found in column 4 of table 6 of Bumgarner and Thompson (2012). The 23 percent is not be confused with the 23 scenarios of Bumgarner and Thompson (2012). Bumgarner and Thompson (2012, p. 17) provided additional details on the simulation methods used for this 2013 investigation.

To numerically replace treatable ashe juniper with grassland, the raster calculator in ArcMap 9.3.1 was used to change the NLCD 2006 values from Deciduous Forest, Evergreen Forest, Mixed Forest, and Shrubland to grassland (technically the NLCD Grassland/Herbaceous category) if the cells in the NLCD 2006 raster intersected cells representing Juniper Forest and Juniper Shrubland in the TESCP raster. This method is similar to the removal methods used in the previous TSSWCB feasibility studies (Bednarz and others,
2000; Bumgarner and Thompson, 2012) and the maximum removal scenarios used by Afinowicz and others (2005).

The five scenario land-cover datasets were created to represent the random removal of 20,40,60,80, and 100 percent of the treatable ashe juniper. The "Create Random Raster" tool of ArcMap 9.3.1 was used and created a raster of uniform-variate values (uniformly distributed real numbers on the open interval of 0 to 1 ) per raster cell. A default seed for the random-number generator was used. The raster cells are about $8.36 \mathrm{~m}$ by $8.36 \mathrm{~m}$. The random raster then was effectively overlaid on the land-cover categories and applicable cells reclassified as grassland from treatable ashe juniper according to probability thresholds of $0.2,0.4,0.6,0.8$, and 1 that represent the five percentage scenarios of 20,40 , 60,80 , and 100 percent, respectively. A systematic approach for grassland conversion was not used because it is outside the scope of this investigation to either ad hoc or objectively identify specific parcels of land (mostly privately owned) for conversion.

For each of the five brush-management scenarios, the HRUs were generated for the upper Guadalupe River SWAT by using the modified land-cover dataset that corresponded with the percentage brush management, and model parameters associated with land cover were accordingly and automatically modified by SWAT software (Neitsch and others, 2011b). Lastly, figure 6 shows the land-cover categories as depicted for the baseline; similar figures representing the five extensive brush-management scenarios could be rendered but were not included in this report because the application of random replacement to grassland process could be confused with suggested locations of rasters or land parcels for treatment. A comparison of treatable ashe juniper acreage to results of Bumgarner and Thompson (2012) is shown in appendix 3.

\section{Relative (Between Scenario to Baseline) Effects of Extensive Brush-Management Scenarios}

The relative (between scenario to baseline) effects of extensive brush-management scenarios were determined by using the SWAT-WAM linkage. Two critical, intermediate results were total inflow (streamflow and tributary inflow) to Canyon Lake for the period 1995-2010 and monthly storage of Canyon Lake for the period 1974-89 (synthetic). These intermediate results are each discussed in the sections that follow. Time series data of Canyon Lake inflow are shown in figure 7 and monthly storage data of Canyon Lake are shown in figure 8 . There is considerable overplotting of the scenarios in figure 8 because the results for different scenarios were often similar or numerically identical (particularly in the earlier parts of the time series); the numerical comparisons described best identify generalized differences. 


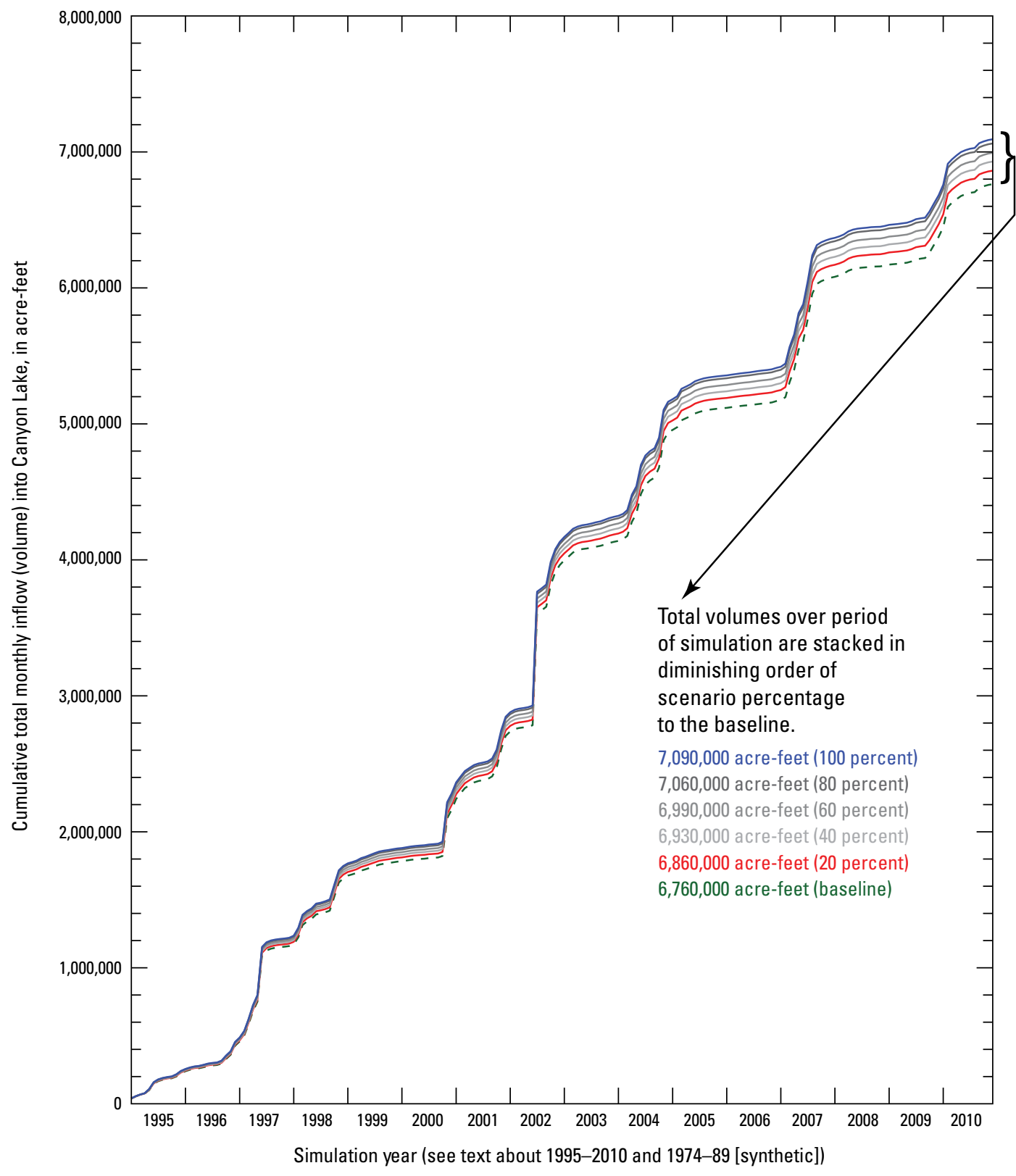

\section{EXPLANATION}

- - - - Soil and Water Assessment Tool (SWAT) baseline scenario (0-percent brush management) Cumulative inflow from SWAT 20-percent treatable brush-management scenario Cumulative inflow from SWAT 40-percent treatable brush-management scenario Cumulative inflow from SWAT 60-percent treatable brush-management scenario Cumulative inflow from SWAT 80-percent treatable brush-management scenario * Cumulative inflow from SWAT 100-percent treatable brush-management scenario

* Almost indistinguishable from 100-percent scenario.

Figure 7. Relation between cumulative volume and time for total monthly inflow to Canyon Lake as simulated by Soil and Water Assessment Tool (SWAT), which includes main stem of Guadalupe River and peripheral drainage to Canyon Lake. Downloadable files for these data are described in appendix 1. 


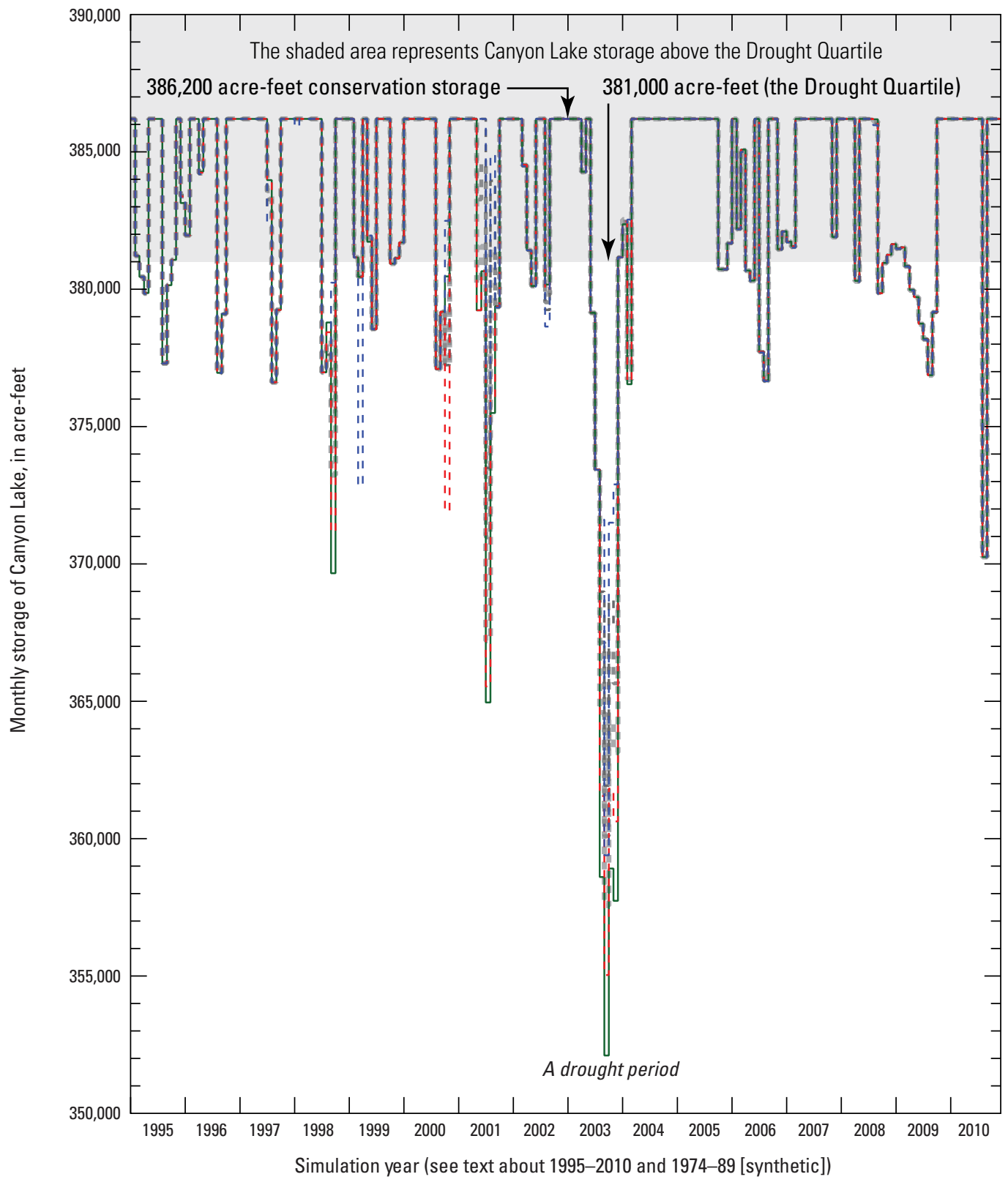

\section{EXPLANATION}

Soil and Water Assessment Tool (SWAT) baseline scenario (0-percent brush management) Cumulative inflow from SWAT 20-percent treatable brush-management scenario

Cumulative inflow from SWAT 40-percent treatable brush-management scenario

- - - - Cumulative inflow from SWAT 60-percent treatable brush-management scenario

- - - - Cumulative inflow from SWAT 80-percent treatable brush-management scenario *

- - - - Cumulative inflow from SWAT 100-percent treatable brush-management scenario

* Almost indistinguishable from 100-percent scenario.

Figure 8. Relation between monthly storage and time of Canyon Lake determined by using Soil and Water Assessment Tool (SWAT) output shown in figure 7 as (1974-89, synthetic) input to the Guadalupe River Water Availability Model (WAM) at control point 2 (CP02, U.S. Geological Survey streamflow-gaging station 08167500 Guadalupe River near Spring Branch, Texas, figs. 2 and 3) for the period 1995-2010. Downloadable files for these data are described in appendix 2. 


\section{Total Inflow to Canyon Lake, 1995-2010}

SWAT simulated cumulative total monthly inflows to Canyon Lake for the period 1995-2010 (a true time period of SWAT simulation) for each of the five brush-management and the baseline scenarios are shown on figure 7 , and the six cumulative volumes also are annotated. The mean annual inflow (acre-feet per year) to Canyon Lake per scenario can be computed (not reported here) by dividing one of the total volumes by 16 (for the 16 years of simulation). Differences between the mean annual inflows to Canyon Lake per scenario are indicative of the relative incremental volumetric changes per scenario.

The first quartile or lower 25th percentile of monthly storage (the Drought Quartile) of Canyon Lake for the 192 months of the baseline scenario (1974-89, synthetic) was computed to be 381,000 acre-ft (fig. 8). The Drought Quartile is a conceptual and heuristically determined waypoint for the analysis herein and is not related to any administrative definition of drought by stakeholders or policy makers. The Drought Quartile of monthly storage for the baseline scenario was chosen for analysis for two critical purposes. First, Canyon Lake is managed by the U.S. Army Corps of Engineers (2013) with a conservation pool of about 386,200 acre-ft capacity (fig. 8) and is at or near conservation capacity about 50 percent or more of the time (as provided by the baseline scenario executed through the Guadalupe River WAM); intrinsic data censoring occurs in the distribution of monthly storage values because of the intent to manage Canyon Lake at conservation pool elevation. This intrinsic censoring has the effect of creating a bounded distribution with a left or low-volume tail; thus, a normal or approximately normal distribution (Helsel and Hirsch, 2002) of monthly storage values does not occur, and the actual lower quartile of Canyon Lake monthly storage during SWAT calibration period (1995-2012) can differ from 381,000 acre-ft for the 192 months of the baseline scenario (1974-89, synthetic).

Statistical assessment of the brush-management scenarios numerically distinct or "away" from the 381,000 acre-ft censoring threshold provides readily interpretable results. The intrinsic data censoring is important to recognize because general increases in monthly streamflow as a result of ashe juniper removal are arguably mostly unavailable for water supply for CP03 because Canyon Lake is already at or near conservation capacity more than 50 percent of the time. The median monthly storage for the baseline scenario linked through the WAM is 386,200 acre-ft, which implies that any "excess" inflow when Canyon Lake is at conservation capacity exits the reservoir through processes such as evaporation or outflow more than 50 percent of the time for the study period. Second, the quantification of brush management during periods lacking abundant rainfall, which were defined in this study as months for which Canyon Lake storage is below the lower quartile (the Drought Quartile) for the simulation period, are of substantial interest to water-resource managers and stakeholders associated with the TSSWCB Water Supply
Enhancement Program and the emphasis towards enhancing water supply (not just streamflow in and of itself) through brush management. The comparisons of cumulative volume in Canyon Lake and treated ashe juniper yields to results in Bumgarner and Thompson (2012) are made in appendix 3.

\section{Monthly Storage of Canyon Lake, 1974-89 (synthetic) from Extensive Brush-Management Scenarios}

SWAT calibration as used for this investigation was oriented around minimization of "the differences between simulated and measured [monthly] streamflows" (Bumgarner and Thompson, 2012, p. 22). Canyon Lake is not in Drought Quartile conditions about 75 percent of the time, and because SWAT is not uniquely calibrated during periods lacking abundant rainfall such as the Drought Quartile, there are uncertainties in absolute values of SWAT-simulated monthly streamflow as well as WAM-computed monthly storage.

There are uncertainties in the SWAT-WAM linkage and scenarios that are difficult to quantify, such as the postsimulation offsetting of SWAT by -21 years to link into the Guadalupe WAM. Cumulative volumes and mean monthly offset storage values obtained from the mean of the lower quartile of Canyon Lake storage were used for the purpose of making relative comparisons between different scenarios. The term "offset storage" represents the subtraction of the mean of the lower quartile storage, and the context of the adject offset here is not related to the -21 year time offset previously described. This approach to making relative comparison helps mitigate interpretation complications arising from the ad hoc offset of the upper Guadalupe River SWAT simulations (19952010 ) to the 1974-89 (synthetic) period of the Guadalupe River WAM.

Time series data of cumulative monthly inflow to Canyon Lake for the different treatable brush-management scenarios are depicted in figure 7. General similarity between the different scenarios is evident during the first several years of simulation, with cumulative differences gradually becoming increasingly discernible over time. The cumulative totals for monthly inflow to Canyon Lake for the entire 1995-2010 simulation period range from $6,760,000$ acre- $\mathrm{ft}$ for the baseline scenario to 7,090,000 acre-ft for the 100-percent removal of treatable brush scenario (fig. 7).

Changes in simulated monthly storage in Canyon Lake are depicted in figure 8 . The conservation storage of Canyon Lake is about 386,200 acre-ft and represents the maximum storage, which periodically occurred during periods of abundant rainfall from 1995 to 2010 . These periods of maximum storage are of comparatively less interest in the context of brush management associated with ashe juniper within the upper Guadalupe River watershed than are the effects of ashe juniper management on water-supply enhancement during periods lacking abundant rainfall. An example drought period defined by the Drought Quartile is 
evident some time during 2003 (fig. 8). Discernible increases in the monthly storage of Canyon Lake (fig. 8) are generally evident during the Drought Quartile for the brush-management scenarios.

SWAT calibration used for the 2013 investigation was oriented around minimization of "the differences between simulated and measured [monthly] streamflows" (Bumgarner and Thompson, 2012, p. 22). Canyon Lake was not in Drought Quartile conditions about 75 percent of the time, with an explicit acknowledgment that the actual lower quartile of Canyon Lake monthly storage during SWAT calibration period (1995-2012) might differ from 381,000 acre-ft for the 192 months of the baseline scenario for 1974-89 (synthetic). Because SWAT is not uniquely calibrated during periods lacking abundant rainfall such as the Drought Quartile, there are uncertainties in the absolute values of monthly streamflow simulated by SWAT as well as the monthly storage computed by the WAM.

There are uncertainties in the SWAT-WAM linkage and scenarios, such as the postsimulation offsetting of SWAT by -21 years, considered to link into the Guadalupe WAM that are difficult to quantify. The use of comparisons through the depiction of cumulative volumes and mean monthly offset storage values from the mean storage of the lower-quartile of Canyon Lake storage should mitigate for interpretation complications concerning the ad hoc offset of the upper Guadalupe River SWAT simulations (1995-2010) to the 1974-89 (synthetic) period of the Guadalupe River WAM.

The five scenarios and the baseline scenario simulated in the upper Guadalupe River SWAT by Bumgarner and Thompson (2012) were passed through the Guadalupe River WAM by the SWAT-WAM linkage described in this report. A comparison of the mean increase per month in reservoir storage for Canyon Lake conditioned for periods lacking abundant rainfall (the Drought Quartile, storage less than 381,000 acre-ft) was made.

For each of the five brush-management scenarios and the baseline by Bumgarner and Thompson (2012), the months with storage below 381,000 acre-ft were extracted. There were 48 months below the lower quartile of the baseline scenario for each of the five scenarios, in which 48 divides into 192 exactly four times as expected. The mean monthly storages during the Drought Quartile were computed for each of the five scenarios and the baseline scenario by summing the monthly storage for the 48 months and dividing by 48 . The mean of the baseline scenario was 376,458 acre-ft. The mean value of 376,458 acre- $f t$ for the baseline scenario subsequently was subtracted from the mean monthly storage during the Drought Quartile for each of the five scenarios. The purpose of the subtraction was to reduce numerical magnitude to make relative comparisons to the baseline easier to express and to mitigate for interpretation complications concerning the -21 -year time offset.

The mean monthly offset storages of Canyon Lake during the Drought Quartile were 110 acre-ft (20 percent); 448 acre-ft (40 percent); 754 acre-ft (60 percent); 1,080 acre-ft
(80 percent); and 1,090 acre-ft (100 percent). A particular mean can be interpreted as follows: the 754 acre-ft for the 60-percent brush-management scenario implies that, on average, this scenario indicates an additional 754 acre-ft per month of storage in Canyon Lake relative to the baseline during the Drought Quartile.

All of the scenarios resulted in an increase on average to water supply during the Drought Quartile through the SWATWAM linkage; however, an observation was made that any of the scenarios numerically resulted in at least a month of apparent decrease in water storage (as seen in a small fraction of months for the 20- [such as October 2000] and 100-percent [such as March 1999] scenarios dropping below the baseline storage time series in fig. 8).

By inspection of the relative change in the mean monthly offset values per scenario, it appeared as though the 100-percent brush-management scenario was only marginally larger than the 80-percent scenario and, therefore, the 80 -percent brush-management scenario likely provided for more water-supply enhancement relative to imparted effort than the 100-percent scenario. The 80-percent brushmanagement scenario seemingly achieved more relative water-supply enhancement than the 100-percent scenario did because it is incrementally quite similar to the 100 -percent scenario: 1,090 acre-ft (100 percent) versus 1,080 acre-ft (80 percent) mean monthly offset storage. The incremental water-supply enhancement during the Drought Quartile from the 80-percent to 100-percent brush-management scenario was about 10 acre-ft storage per month. During Drought Quartile conditions, the order of storage change was about 828 acre-ft per 0.1-foot change in water-surface elevation. The incremental water-supply enhancement from the 80 -percent to the 100-percent scenario was on the order of 0.01 -feet per month (approximately 10 acre-ft divided by 828 acre-ft per 0.1-foot change); therefore, the 80 -percent scenario was reasoned to provide about as much water-supply enhancement as the 100-percent scenario on the basis of the methods used.

The consideration of monthly storage changes in the context of the storage change per change in water-surface elevation (made for the aforementioned 80- to 100-percent scenario comparison) provides alternative perspective to storage. The mean monthly storage change for each of the five scenarios was considered in terms of expected monthly increase in water-surface elevation of Canyon Lake. The mean monthly storage changes, which were based on the 828 acre-ft per 0.1-foot change applicable for the Drought Quartile threshold of 381,000 acre-ft, were about 0.01 foot ( 20 percent), about 0.05 foot ( 40 percent), about 0.1 foot ( 60 percent), about 0.13 foot ( 80 percent), and about 0.13 foot (100 percent). For example, the value of 0.05 foot for the 40-percent scenario was computed by 448 acre-ft divided by 828 acre-ft per 0.1-foot change. Each of the five extensive brush-management scenarios therefore was expected to produce a monthly water-supply enhancement at least equal to the incremental resolution of USGS measurements of watersurface elevation (0.01 foot) for Canyon Lake within the 
USGS National Water Information System (U.S. Geological Survey, 2013). Asquith and others (2007) provides additional details for water-surface-elevation measurements done by the USGS in Texas.

\section{Discussion of Result Sensitivity}

Because this report serves in part as documentation of a proof of concept on the feasibility of linking previously published models, SWAT and WAM, and for other reasons that follow, sensitivity analysis of the results herein would be inherently problematic to complete, and if it could be done, it would potentially subject the results to overinterpretation regarding the precision of the simulations generated by linking the models. It is difficult to identify a quantitative approach that would combine basic uncertainty (variation) in SWAT and WAM. Bumgarner and Thompson (2012) described various calibration biases and uncertainties. It also is difficult to assess the potential variability of the WAM because numerical uncertainty is not a component of the output files; thus, the authors are confronted with one model with a quantification of uncertainty and another with neither qualification nor quantification of uncertainty, specifically pertaining to Canyon Lake storage.

The offset of -21 years to force a temporal linkage between the two time periods is a large jump in logic that greatly increases difficulty in either quantification or qualification of result sensitivity. Cursory inspection of observed streamflow (not SWAT modeled flow) at the Spring Branch streamgage for January 1974 (289 cubic feet per second $\left.\left[\mathrm{ft}^{3} / \mathrm{sec}\right]\right)$ and January $1995\left(377 \mathrm{ft}^{3} / \mathrm{sec}\right)$ (U.S. Geological Survey, 2013) indicates that hydrologic conditions are similar for the two periods. Canyon Lake monthly storage for the baseline scenario offset -21 years begins the 1974-89 (synthetic) time series at conservation capacity, which replicates storage conditions for January 1974 of the unmodified Guadalupe River WAM.

This section provides an opportunity to discuss how the linkage effort could be improved. First, recalibration of SWAT to a 1974-89 (nonsynthetic) period might be possible, but it is likely that the 1970s and 1980s landscape in terms of treatable ashe juniper differed appreciably from treatable ashe juniper landscape of concern to brush-management stakeholders in 2013, and the fundamental quality and quantity of land-use data during the 1970s and 1980s is difficult to assess. The authors prefer circumstances of use of the current SWAT model or possible future derivatives. The data used in the WAM ended in December 1989, and through 2013 there was not a priority for further temporal extension of the data used in the WAM because the drought of the 1950s remained the historic drought of record for water-availability modeling purposes (Tommy Hill, Guadalupe-Blanco River Authority, oral commun., November 20, 2013). The possibility of completing a robust sensitivity analysis of SWAT-WAM in the context of the study area is dependent upon on a WAM update that includes data through 2010, but such an update is outside the scope of this investigation.

\section{Summary}

The selective or managed removal of woody plants (brush management of nonherbaceous and nonsucculent plants) in an effort to potentially increase or enhance water availability for downstream water bodies is a conservation practice used in Texas in 2013. Ashe juniper (Juniperus ashei) is a species of woody plant that has spread beyond its historical range within the understories of prairie oak motte (small stands) and within sheltered canyons in south-central Texas. Studies of the water use of ashe juniper indicated that the species might intercept and subsequently enhance evaporation as well as generally use more water than native grasses use. The replacement in south-central Texas of ashe juniper with grasslands is intended to increase water yields from managed land parcels.

In an effort to help constrain the potential for watersupply enhancement by ashe juniper management in the upper Guadalupe River watershed, the U.S. Geological Survey, in cooperation with the Texas State Soil and Water Conservation Board, developed and applied an approach to create a linkage between straightforward extensions from a previous upper Guadalupe River Soil Water Assessment Tool (SWAT) feasibility study and the full authorization version Guadalupe River Water Availability Model (WAM). The Guadalupe River WAM is available from the Texas Commission on Environmental Quality (TCEQ). The upper Guadalupe River watershed is a substantial component of the Guadalupe River WAM. This report serves in part as documentation of a proof of concept on the feasibility of linking these two waterresources planning models for the purpose of simulating possible increases in water storage in Canyon Lake as a result of different brush-management scenarios.

The primary purpose of this report is to document the SWAT-WAM linkage for the upper Guadalupe River with a principal objective to evaluate the distributional characteristics of monthly storage of Canyon Lake in the context of water supply during periods lacking abundant rainfall. This report is focused on relative (between scenario to baseline) evaluation of select scenarios of large-scale or extensive brush management within the upper Guadalupe River watershed. There are six SWAT simulations that include a baseline (0-percent management of treatable ashe juniper, the baseline scenario from a previous study in which no ashe juniper is replaced with grassland) along with five scenarios (extensions of SWAT simulations from a previous study) of 20-, 40-, 60-, $80-$, and 100-percent random (numerical) replacement of treatable ashe juniper with grasslands throughout the upper Guadalupe River watershed.

The Guadalupe River Basin extends about 230 miles from its headwaters in the Edwards Plateau in south-central 
Texas to San Antonio Bay near Tivoli and has a total drainage area of about 10,200 square miles $\left(\mathrm{mi}^{2}\right)$. The study area for this investigation was the upper Guadalupe River watershed (shaded area) and represents about 1,432 $\mathrm{mi}^{2}$ of the Guadalupe River Basin upstream from the dam for Canyon Lake.

Particularly pertinent to this investigation is U.S. Geological Survey streamflow-gaging station 08167500 Guadalupe River near Spring Branch, Texas (hereinafter the Spring Branch streamgage). Three major tributaries (Rebecca Creek, Jentsch Creek, and Tom Creek) are each downstream from the Spring Branch streamgage and are either nearupstream or direct tributaries to Canyon Lake. The watersheds for the three creeks are named within the Guadalupe River WAM and represent specific control points. Adjustments to these three watersheds were needed for computational consistency of water-budget equations to implement the SWAT-WAM linkage.

SWAT is a process-based, semidistributed waterbalance model designed to predict the effects of landscape management decisions on water, sediment, and agricultural chemical yields. In SWAT, a watershed is subdivided into subbasins, and each subbasin is associated with a single reach on the stream network. Each subbasin is further divided into hydrologic response units that consist of unique combinations of land cover, soil characteristics, land slope, and land-management criteria. The upper Guadalupe River SWAT encompasses the period of monthly record 1995-2010 (January through December).

In general, a WAM, such as the Guadalupe River WAM, provides for generalized water-rights analysis in a river and reservoir framework. A WAM accommodates hydrology and water usage through several input files that contain water rights, watershed parameters, and naturalized streamflow sequences. A WAM is generalized for application to river and reservoir systems, and input datasets are uniquely developed for a river basin of concern.

The extractions of SWAT output for the five extensive brush-management and baseline scenarios were offset by -21 years, and in general the results were then mapped to (a term that evokes the mathematical notation that was used) the WAM input-flow file. The offset of -21 years means that the period of monthly record 1995-2010 of the upper Guadalupe River SWAT becomes a synthetic period of monthly record 1974-89, hereinafter the 1974-89 (synthetic), of the Guadalupe River WAM.

For depiction of SWAT output preprocessing and reformatting, a diagram with attendant description through an embedded Glossary/Nomenclature/Description section is shown. The starting point of the linkage is the monthly streamflow emanating from SWAT that is coincident with the Guadalupe River watershed monitored by the Spring Branch streamgage. This streamgage also is coincident with Reach 85 (RCH85) of SWAT, and RCH85 values for a single simulation scenario were extracted from the $\mathrm{RCH}$ plain-text file. For depiction of WAM modification and logic, another diagram with attendant description through an embedded Glossary/Nomenclature/Description section is shown. The schematic and corresponding symbols were deliberately chosen to represent those portions of four drainage-area WAM parameters requiring slight modification to support linkage to SWAT with an objective to achieve the slightest modification possible (only four parameters altered) to the otherwise officially accepted Guadalupe River WAM. Drainage areas and their respective influences on WAM operation are important and especially noted on the diagram. There are three tributaries recognized in the Guadalupe River WAM as well as the remaining unnamed aggregate drainage into Canyon Lake. These four watersheds are controlled by deliberate adjustment of the drainage areas in a WAM parameter file. The three named tributaries in the WAM are Rebecca Creek (G921 control point), Jentsch Creek (G907 control point), and Tom Creek (G908 control point). Because each of the four watersheds is numerically encountered during WAM execution, the change in drainage area was chosen as $0.01 \mathrm{mi}^{2}$ to be vanishingly small for the SWAT-WAM linkage.

Five modified land-cover datasets were selected to evaluate the relative potential for extensive brush management for water-supply enhancement in the upper Guadalupe River watershed. The baseline scenario considered for this investigation (0-percent ashe juniper management) is the same as the nontreatment calibration scenario in a previous study. Modified datasets from that study were generated by randomly replacing 20, 40, 60, 80, and 100 percent of the treatable ashe juniper (ashe juniper that could potentially be replaced with grassland through extensive brush management).

The five scenario land-cover datasets were created to represent the random removal of $20,40,60,80$, and 100 percent of the treatable ashe juniper. Geographical information system software was used to create a raster of uniformvariate values (uniformly distributed real numbers on the open interval of 0 to 1 ) per raster cell. A default seed for the random-number generator was used. The raster cells were about 8.36 meters by 8.36 meters. The random raster then was effectively overlaid on the land-cover categories and applicable cells reclassified as grassland from treatable ashe juniper according to probability thresholds of $0.2,0.4,0.6,0.8$, and 1 that represent the five percentage scenarios of 20, 40, 60, 80 , and 100 percent, respectively.

The relative effects of extensive brush-management scenarios obtained by using the SWAT-WAM linkage were evaluated, and two critical intermediate results were total inflow to Canyon Lake for 1995-2010 and monthly storage of Canyon Lake for 1974-89 (synthetic). The cumulative total monthly inflows (streamflow and tributary inflow) to Canyon Lake for the baseline and for each of the five brushmanagement and baseline scenarios are presented, and this streamflow represents total inflow to Canyon Lake for the period 1995-2010 (a true period of SWAT simulation). 
Differences between the annual inflows to Canyon Lake per scenario represent the incremental volumetric changes per scenario.

The first quartile or lower 25 th percentile of monthly storage of Canyon Lake for the 192 months of the baseline scenario for 1974-89 (synthetic) was 381,000 acre-feet (acre-ft). This lower quartile of monthly storage for the baseline time series was chosen for analysis for two critical purposes. First, Canyon Lake was managed with a conservation pool of about 386,200 acre-ft capacity and was at or near conservation capacity about 50 percent or more of the time (provided by the baseline scenario executed through the Guadalupe River WAM); further, there was intrinsic data censoring that occurred for monthly storage distribution because of the intent to manage Canyon Lake at conservation pool elevation. This intrinsic censoring has the effect of creating a bounded distribution with a left or low-volume tail. Statistical assessment of the brush-management scenarios away from the 381,000 acre-ft censoring threshold provided readily interpretable results. This data censoring is important to recognize because, although numerically within SWAT the replacement of ashe juniper with grasslands increases water yields, many increases in monthly streamflow as a result of ashe juniper removal are arguably unavailable for water supply because Canyon Lake is already at or near conservation capacity over 50 percent of the time. The median monthly storage for the baseline scenario linked through the WAM was 386,200 acre-ft, which implied by logical extension that any "excess" inflow to Canyon Lake exited the reservoir through processes such as evaporation or outflow above conservation pool elevation. Second, the quantification of brush management during periods lacking abundant rainfall, which were defined in this study as months for which Canyon Lake storage below its lower quartile for the simulation period, are of substantial interest to water-resource managers and stakeholders in the context of water-supply enhancement (not just streamflow in and of itself) through brush management.

Time series data of monthly storage of Canyon Lake for the two end-member scenarios (baseline and 100 percent) indicate that the 100-percent scenario plots higher than the baseline scenario during four drought periods. General similarity between the different scenarios is evident during the first several years of simulation, with cumulative differences gradually becoming increasingly discernible over time. The cumulative totals for monthly inflow to Canyon Lake for the entire 1995-2010 simulation period range from 6,760,000 acre-ft for the baseline scenario to 7,090,000 acre-ft for the 100-percent removal of treatable brush scenario.

The conservation storage of Canyon Lake was about 386,200 acre-ft, represented the maximum storage, and was associated with typical climatic periods and periods of abundant rainfall. Such periods in the context of brush management associated with ashe juniper within the upper Guadalupe River watershed were of comparatively less interest during this study than the effects of ashe juniper management on water-supply enhancement during drought periods. A statistical assessment of the SWAT-WAM linkage for the left or low-volume tail of the distribution of monthly storage of Canyon Lake was the focus of analysis and interpretation. Drought periods for the analysis were defined as the months (consecutive or not) for which Canyon Lake is below the 25th percentile of storage (381,000 acre-ft) for the baseline scenario. Such months are referred to as within the "Drought Quartile." The Drought Quartile is a conceptual and heuristically determined waypoint for the analysis herein and is not related to any administrative definition of drought by stakeholders or policy makers.

The five extensive brush-management and baseline scenarios simulated in the upper Guadalupe River SWAT were all passed through the Guadalupe River WAM by the SWATWAM linkage described in this report. A comparison of the mean increase per month in reservoir storage for Canyon Lake conditioned for periods lacking abundant rainfall (the Drought Quartile, with storage less than 381,000 acre-ft) was made.

For each of the five brush-management and baseline scenarios, the months with storage below 381,000 acre-ft were extracted. The mean monthly storages during the Drought Quartile were computed for each of the five scenarios and the baseline scenario. The mean of the baseline scenario was 376,458 acre-ft and subsequently was subtracted from the mean monthly storage during the Drought Quartile for each of the five scenarios. The purpose of the subtraction is to reduce numerical magnitude to make comparisons to the baseline easier to express and to mitigate for interpretation complications concerning the -21 -year time offset.

The mean monthly offset storages of Canyon Lake during the Drought Quartile were 110 acre-ft (20 percent); 448 acre-ft (40 percent); 754 acre-ft (60 percent); 1,080 acre-ft (80 percent); and 1,090 acre-ft (100 percent). A particular mean can be interpreted as follows: the 754 acre-ft for the 60-percent brush-management scenario implies that, on average, this scenario indicates an additional 754 acre-ft per month of storage in Canyon Lake relative to the baseline during the Drought Quartile. All of the scenarios result in an increase on average to water supply during the Drought Quartile through the SWAT-WAM linkage.

By inspection of the relative change in the mean monthly offset values per scenario, it appeared as though the 100-percent brush-management scenario was only marginally larger than the 80-percent scenario and, therefore, the 80-percent brush-management scenario likely provided for more water-supply enhancement relative to imparted effort than the 100-percent scenario. The 80-percent brushmanagement scenario seemingly achieved more relative watersupply enhancement than the 100-percent scenario because it is incrementally quite similar to the 100 -percent scenario: 1,090 acre-ft (100 percent) versus 1,080 acre-ft ( 80 percent) mean monthly offset storage.

The incremental water-supply enhancement during the Drought Quartile from the 80-percent to 100-percent brushmanagement scenario was about 10 acre-ft storage per month. During Drought Quartile conditions, the order of storage change was about 828 acre-ft per 0.1 -foot change in watersurface elevation. The incremental water-supply enhancement 
from the 80 -percent to the 100-percent scenario was on the order of 0.01 -foot per month (approximately 10 acre- $\mathrm{ft}$ divided by 828 acre-ft per 0.1 -foot change). Therefore, the 80 -percent scenario was reasoned to provide about as much water-supply enhancement based on the methods used.

The consideration of monthly storage changes in the context of the storage change per change in water-surface elevation provided alternative perspective. The mean monthly storage change for each of the five scenarios was considered in terms of expected monthly increase in water-surface elevation of Canyon Lake. The mean monthly storage changes, which were based on the 828 acre-ft per 0.1 -foot change applicable for the Drought Quartile threshold of 381,000 acre-ft, were about 0.01 foot ( 20 percent), about 0.05 foot ( 40 percent), about 0.1 foot ( 60 percent), about 0.13 foot ( 80 percent), and about 0.13 foot (100 percent). Each of the five extensive brush-management scenarios therefore is expected to produce a monthly water-supply enhancement at least equal to the incremental resolution of USGS measurements of watersurface elevation ( 0.01 foot) for Canyon Lake within the USGS National Water Information System.

\section{References}

Afinowicz, J.D., Munster, C.L., and Wilcox, B.P., 2005, Modeling effects of brush management on the rangeland water budget-Edwards Plateau, Texas: Journal of the American Water Resources Association, v. 41, no. 1, p. 181-193.

Archer, Steve, 1989, Have southern Texas savannas been converted to woodlands in recent history?: The American Naturalist, v. 134, no. 4, p. 545-561.

Archer, Steve, Schimel, D.S., and Holland, E.A., 1995, Mechanisms of shrubland expansion-Land use, climate or $\mathrm{CO}_{2}$ ?: Climate Change, v. 29, no. 1, p. 91-99.

Archer, Steve, Scifres, Charles, Bassham, C.R., and Maggio, Robert, 1988, Autogenic succession in a subtropical savanna-Conversion of grassland to thorn woodland: Ecological Monographs, v. 58, no. 2, p. 111-127.

Arnold, J.G., Srinivasan, Raghavan, Muttiah, R.S., and Williams, J.R., 1998, Large area hydrologic modeling and assessment part I-Model development: Journal of the American Water Resources Association, v. 34, no. 1, p. 73-89.

Asquith, W.H., Roussel, M.C., and Vrabel, Joseph, 2006, Statewide analysis of the drainage-area ratio method for 34 streamflow percentile ranges in Texas, U.S. Geological Survey Scientific Investigations Report 2006-5286, 34 p., 1 appendix.
Asquith, W.H., and Roussel, M.C., 2007, An initialabstraction, constant-loss model for unit hydrograph modeling for applicable watersheds in Texas: U.S. Geological Survey Scientific Investigations Report 20075243, 82 p.

Asquith, W.H., Vrabel, Joseph, and Roussel, M.C., 2007, Summary of water-surface-elevation data for 116 U.S. Geological Survey lake and reservoir stations in Texas and comparison to data for water year 2006: U.S. Geological Survey Data Series 287, 44 p.

Banta, J.R., and Slattery, R.N., 2011, Effects of brush management on the hydrologic budget and water quality in and adjacent to Honey Creek State Natural Area, Comal County, Texas, 2001-10: U.S. Geological Survey Scientific Investigations Report 2011-5226, 35 p.

Baxter, David, 2009, Selah, Bamberger Ranch PreserveLeopold/Lone Star Land Steward Award: Texas Wildlife Magazine, accessed April 9, 2011, at http://brp-journal. blogspot.com/2009/09/selah-bamberger-ranch-preserve. html.

Bednarz, S.T., Dybala, Tim, Muttiah, R.S., Rosenthal, Wes, and Dugas, W.A., 2000, Brush management/water yield feasibility studies for eight watersheds in Texas: Texas Water Resources Institute Report TR-182, p. 1-21.

Bumgarner, J.R., and Thompson, F.E., 2012, Simulation of streamflow and the effects of brush management on water yields in the upper Guadalupe River watershed, south-central Texas, 1995-2010: U.S. Geological Survey Scientific Investigations Report 2012-5051, 25 p.

Dugas, W.A., Hicks, R.A., and Wright, Phillip, 1998, Effect of removal of Juniperus ashei on evapotranspiration and runoff in the Seco Creek watershed: Water Resources Research, v. 34, no. 6, p. 1499-1506.

Environmental Systems Research Institute, Inc., 2009, ArcGIS Desktop 9.3-Data and maps, Mexico base 1:300,000 (hydrography): Redlands, Calif., Environmental Systems Research Institute, Inc., accessed August 24, 2010, at http:// www.esri.com/.

Fry, J.A., Xian, George, Jin, Suming, Dewitz, J.A., Homer, C.G., Yang, Limin, Barnes, C.A., Herold, N.D., and Wickham, J.D., 2011, Completion of the 2006 National Land Cover Database for the conterminous United States: Photogrammetric Engineering and Remote Sensing, v. 77, no. 9, p. 858-864.

Fuhlendorf, S.D., Smeins, F.E., and Grant, W.E., 1996, Simulation of a fire-sensitive ecological threshold-A case study of Ashe juniper on the Edwards Plateau of Texas, USA: Ecological Modelling, v. 90, no. 3, p. 245-255. 
Fuhlendorf, S.D., Smeins, F.E., and Taylor, C.A., Jr., 1997, Browsing and tree size influences on Ashe juniper understory: Journal of Range Management, v. 50, p. $507-512$.

Garcia, A.M., 2009, Simulation of water quality in the Tull Creek and West Neck Creek watersheds, Currituck Sound Basin, North Carolina and Virginia: U.S. Geological Survey Scientific Investigations Report 2008-5226, 22 p.

Gesch, Dean, 2007, The National Elevation Dataset, in Maune, David, ed., Digital elevation model technologies and applications-The DEM users manual (2d ed.): Bethesda, Md., American Society for Photogrammetry and Remote Sensing, p. 99-118.

Gesch, Dean, Oimoen, Michael, Greenlee, Susan, Nelson, Charles, Steuck, Michael, and Tyler, Dean, 2002, The National Elevation Dataset: Photogrammetric Engineering and Remote Sensing, v. 68 , no. 1, p. 5-11.

Humphrey, R.R., 1958, The desert grassland-A history of vegetational change and an analysis of causes: The Botanical Review, v. 24, no. 4, p. 193-252.

Huxman, T.E., Wilcox, B.P., Breshears, D.D., Scott, R.L., Snyder, K.A., Small, E.E., Hultine, Kevin, Pockman, W.T., and Jackson, R.B., 2005, Ecological implications of woody plant encroachment: Ecology, v. 86, p. 308-319.

Katz, B.G., DeHan, R.S., Hirten, J.J., and Catches, J.S., 1997, Interactions between ground water and surface water in the Suwanee River Basin, Florida: Journal of the American Water Resources Association, v. 33, p. 1237-1254.

Larkin, T.J., and Bomar, G.W., 1983, Climatic atlas of Texas: Texas Department of Water Resources, Limited Printing Report LP-192, 151 p.

Musgrove, MaryLynn, Stern, L.A., and Banner, J.L., 2010, Springwater geochemistry at Honey Creek State Natural Area, central Texas-Implications for surface water and groundwater interaction in a karst aquifer: Journal of Hydrology, v. 388, p. 144-156.

Natural Resources Conservation Service, 2009, National Conservation Practice Standard Code 314: U.S. Department of Agriculture, $4 \mathrm{p}$.

Natural Resources Conservation Service, 2011, Soil Survey Geographic (SSURGO) Database for Texas: accessed January 10, 2011, at http://datagateway.nrcs.usda.gov.

Natural Resources Conservation Service, 2012, Watershed boundary dataset: U.S. Department of Agriculture, accessed February 17, 2012, at http://www.ncgc.nrcs.usda.gov/ products/datasets/Watershed/.
Neitsch, S.L., Arnold, J.G., Kiniry, J.R., and Williams, J.R., 2011a, Soil and Water Assessment Tool theoretical documentation, version 2009: Temple, Tex., Grassland, Soil and Water Research Laboratory, Agricultural Research Service. (Also available at http://twri.tamu.edu/ reports/2011/tr406.pdf.)

Neitsch, S.L., Arnold, J.G., Kiniry, J.R., and Williams, J.R., 2011b, Soil and Water Assessment Tool input/output file documentation, version 2009: Temple, Tex., Grassland, Soil and Water Research Laboratory, Agricultural Research Service. (Also available at http://ssl.tamu.edu/media/19754/ swat-io-2009.pdf.)

Owens, M.K., 1996, The roll of leaf and canopy-level gas exchange in the replacement of Quercus virginiana (Fagaceae) by Juniperus ashei (Cupressaceae) in semiarid savannas: American Journal of Botany, v. 83, p. 617-623.

Saleh, Ali, Wu, Hong, Brown, C.S., Teagarden, F.M., McWilliams, S.M., Hauck, L.M., and Millican, J.S., 2009, Effect of brush control on evapotranspiration in the North Concho River watershed using the eddy covariance technique: Journal of Soil and Water Conservation, v. 64, no. 5, p. 336-349.

Smeins, F.E., 1980, Natural role of fire on the Edwards Plateau, in Proceedings, Prescribed Burning of the Edwards Plateau, College Station, Tex.: Texas Agriculture Extension Service, p. 4-16.

Soil Conservation Service, 1986, Urban hydrology for small watersheds: U.S. Department of Agriculture, Conservation Engineering Division, Technical Release 55 [variously paged].

Texas Commission on Environmental Quality, 2013, Water Availability Models: accessed January 31, 2013, at http:// www.tceq.texas.gov/permitting/water_rights/wam.html.

Texas Parks and Wildlife Deparment, 2013, GIS lab map downloads: accessed in December 2013, at http://www. tpwd.state.tx.us/landwater/land/maps/gis/map_downloads/.

Texas State Soil and Water Conservation Board, 2013, Water Supply Enhancement Program: accessed June 25, 2013, at http://www.tsswcb.texas.gov/en/brushcontrol.

Texas Water Development Board, 2001, Volumetric survey of Canyon Lake: Texas Water Development Board, Austin, Tex., November 9, 2001, [variously paged].

Texas Water Development Board, 2011, Water for Texas 2012 State Water Plan: accessed June 20, 2012, at http://www. twdb.state.tx.us/wrpi/swp/swp.asp. 
Thompson, D.B., Harle, Kirt, Keister, Heather, McLendon, David, and Sandrana, S.K., 2003, Climatic adjustments of Natural Resource Conservation Service (NRCS) Runoff Curve Numbers-Final report: Texas Department of Transportation Research Report 0-2104-2, Texas Tech University, Center for Multidisciplinary Research in Transportation, $26 \mathrm{p}$.

U.S. Army Corps of Engineers, 2013, History of Canyon Lake: accessed June 6, 2013, at http://www.swf-wc.usace. army.mil/canyon/Information/History.asp.

U.S. Census Bureau, 2011, 2010 Population finder: accessed September 12, 2011, at http://www.census.gov/popfinder/.

U.S. Geological Survey, 2006, Geologic database of Texas: accessed February 10, 2011, at http://tin.er.usgs.gov/ geology/state/state.php.

U.S. Geological Survey, 2013, National Water Information System: accessed in December 2013 at http://waterdata. usgs.gov/tx/nwis/.

Van Auken, O.W., 2000, Shrub invasions of North American semiarid grasslands: Annual Review of Ecology and Systematics 31, p. 197-215.

Wilcox, B.P., 2002, Shrub control and streamflow on rangelands-A process-based viewpoint: Journal of Range Management, v. 55, p. 318-326.
Wilcox, B.P., and Thurow, T.L., 2006, Emerging issues in rangeland ecohydrology - Vegetation change and the water cycle: Rangeland Ecology and Management, v. 59, p. 220-224.

Winchell, Michael, Srinivasan, Raghavan, Di Luzio, Mauro, and Arnold, Jeffrey, 2010, ArcSWAT interface for SWAT2009 user's guide: Temple, Tex., Blackland Research Center, Texas Agricultural Experiment Station. (Also available at http://swatmodel.tamu.edu/software/arcswat.)

Winter, T.C., Harvey, J.W., Franke, O.L., and Alley, W.M., 1998, Ground water and surface water-A single resource: U.S. Geological Survey Circular 1139, 79 p.

Wurbs, R.A., 2004, Modeling river/reservoir system management, water allocation, and supply reliability: Journal of Hydrology, v. 300, p. 100-113.

Wurbs, R.A., 2011, Water rights analysis package (WRAP) modeling system reference and users manuals: TR-255 and TR-256, 8th ed., Texas Water Resources Institute, College Station, Tex., 548 p.

Wurbs, R.A., and Lee, Chihun, 2011, Incorporation of salinity in Water Availability Modeling: Journal of Hydrology, v. 409, p. 451-459.

Young, J.A., Evans, R.A., and East, D.A., 1984, Stem flow on western juniper (Juniperus occidentalis) trees: Weed Science, v. 32, p. 320-327.
Publishing support provided by Lafayette Publishing Service Center 
